\title{
La interpretación de los derechos fundamentales
}

\section{Edgar Carpio Marcos}

\begin{abstract}
"Il problema grave del nostro tempo era non giá quello di fondarli ma di proteggerli [...]. Il problema che ci sta dinnanzi, infatti, non é filosofico ma giuridico, e in piú largo senso politico. Non si tratta tanto di sapere quali e quanti sono questi diritti, quale sia la loro natura e il loro fondamento, se siano diritti naturali o storici, assolutio relativi, ma quale sia il modo piú sicuro per garantirli, per impedire che nonnostante le dichiarazioni solenni vengano continuamente violativ.

Norberto Bobbio, L'etá dei diritti, Einaudi, Torino 1990, pp. 17-18.
\end{abstract}

\section{Interpretación constitucional e interpretación de los derechos fundamentales}

La problemática de la interpretación de los derechos fundamentales está vinculada a la de la interpretación de la Constitución. Después de todo, el reconocimiento de los derechos fundamentales constituye uno de los chapitre más trascendentales de toda Ley Fundamental y las disposiciones que los enuncian expresan, con mayor evidencia, las cuotas de peculiaridad que se ha destacado para justificar un tratamiento ad hoc de su interpretación. ${ }^{1}$ Es decir, se tratan de normas que tienen una textura abierta, son de un alto contenido valorativo y están dotadas de un grado importante de abstracción y generalidad.

De ahí que, además de los criterios de interpretación de la ley —en sí mismos insuficientes para abordar los problemas que se derivan de la pe-

1 Cfr. Últimamente, Marisa Iglesias Vila, «La interpretación de la Constitución y los conceptos esencialmente controvertidos», en: AA. VV. Teoría Constitucional y derechos fundamentales, Comisión Nacional de Derechos Humanos, México, 2002, p. 443 y ss. 
culiaridad de las normas constitucionales $-^{2}$ en términos generales se admite la traslación de los criterios de interpretación constitucional al campo de los derechos fundamentales, esto es, la aplicación de los principios de unidad de la Constitución, concordancia práctica, eficacia integradora, interpretación conforme, etc. ${ }^{3}$

No obstante, tal aplicación no debe considerarse como una identificación plena con los criterios de interpretación de los derechos, pues, como advierte Klaus Stern, ${ }^{4}$ ello podría incurrir «en el peligro de menospreciar el significado específico que tienen los derechos fundamentales en la vida jurídica y social de un país». A través de los derechos, en efecto, no solo se reconocen un haz de facultades y potestades a favor de cada uno de los individuos (dimensión subjetiva), sino, también, los elementos esenciales del ordenamiento jurídico (dimensión objetiva). Precisamente, en atención a ese doble carácter de los derechos, es que detrás de la interpretación de las cláusulas que los reconocen y la solución de problemas en los que éstos se encuentran envueltos, no solo se decidan cuestiones subjetivas, sino también temas verdaderamente cruciales para el orden político, pues sus alcances repercuten directamente «en la actuación de los poderes legislativo, ejecutivo y judicial, así como en la de todos y cada uno de los miembros de la sociedad». ${ }^{5}$ De ahí que no sea exagerada la opinión de Zacher, para quien en la interpretación de los derechos fundamentales se encuentra "el más importante teatro de batalla en la lucha por la interpretación de la Constitución". ${ }^{6}$

Qué duda cabe que, en ese teatro de batalla, uno de sus protagonistas privilegiados es el Tribunal Constitucional. El papel que este cumple es de extrema importancia, pues, por un lado, tal órgano jurisdiccional es

2 Cfr. sobre el particular Alejandro Nieto, «Peculiaridades jurídicas de la norma constitucional», en: Revista de Administración Pública, $N^{\circ}$ 100-102, Vol. 1, Madrid, 1983, p. 371 y ss.

3 Sobre el tema Cfr. Konrad Hesse, Escritos de Derecho Constitucional, CEC, Madrid, 1992, p. 45 y ss.

4 Klaus Stern, "Riflessioni sull' interpretazione dei diritti fondamentali», en: Diritto e Societá, $\mathrm{N}^{\circ} 2,1995$, p. 213.

5 María Isabel Garrido Gómez, «Aspectos e implicaciones de una interpretación integral-material de los derechos fundamentales», en: Derechos y Libertades, $N^{\circ} 10,2001$, p. 23.

6 H. F. Zacher, Der Staat, Vol. 14, 1975, p. 128, citado por Klaus Stern, «Riflessioni sull' interpretazione dei diritti fondamentalì, en: Diritto e Societá, op. cit., p. 213. 
(donde existe) el intérprete supremo de la Constitución ${ }^{7}$ y, de otro, porque al menos en sede interna, constituye el guardián último de los derechos fundamentales. Es por ello que en la doctrina, cada vez con mayor frecuencia, se realizan esfuerzos por sistematizar los criterios de interpretación que los tribunales constitucionales utilizan (o deberían hacerlo). En algunos casos, a partir de una teoría de los derechos fundamentales, para evitar de ese modo que tales criterios se presenten, como afirma Robert Alexy, como «una colección de topoi sumamente abstractos que pueden ser utilizados según se desee». ${ }^{8}$ En otros, no exigiendo de dichos órganos la asunción de una teoría determinada, pues cada una de aquellas ha elaborado un "complejo semántico» tal, que su comprensión requiere a su vez de un esfuerzo de interpretación, que puede terminar generando un "círculo vicioso": "antes, se toma algo de la norma para formular la teoría, después se imputa la teoría a la norma y se confirma el resultado ya encontrado"?.

Precisamente el propósito de este trabajo es presentar esos topoi, no a partir de una teoría de los derechos fundamentales previamente adoptada, sino, eventualmente, explicitada al compás que se efectúa la descripción de un criterio determinado. $Y$ es que al igual de lo que sucede con la interpretación de la ley e, incluso, con la de las normas constitucionales, ninguno de los criterios de interpretación de los derechos fundamentales a priori deben ser excluidos, pues, en palabras de Häberle, debe procederse a «una integración práctica» de todos ellos. ${ }^{10}$

7 Sobre el particular Ernesto Blume, «El Tribunal Constitucional como supremo intérprete de la Constitución", en: Derecho, N 50, Fondo Editorial de la PUCP, Lima, 1996, p. 125 y ss., Luis Huerta Guerrero, "Jurisprudencia constitucional e interpretación de los derechos fundamentales", en: AA.VV., Derechos fundamentales e interpretación constitucional, Lecturas sobre temas constitucionales, $\mathrm{N}^{\circ} 13$, CAJ, Lima, 1997, p. 23 y ss.

8 Robert Alexy, Teoría de los derechos fundamentales, Centro de Estudios Constitucionales, Madrid, 1997, p. 38.

9 Klaus Stern, «Riflessioni sull' interpretazione dei diritti fondamentali», op. cit., p. 240.

10 Peter Häberle, La libertad fundamental en el Estado Constitucional, Fondo Editorial de la PUCP, Lima, 1997, pp. 273-274, nota 146. Cfr. María del Carmen Barranco, La teoría jurídica de los derechos fundamentales, Dykinson, Madrid, 2000, p. 127 y ss., César Landa, "Teorías de la interpretación constitucional», en su libro Teoría del Derecho Procesal Constitucional, Editorial Palestra, Lima, 2003, p. 245. 


\section{La interpretación de los derechos fundamentales como proble- ma jurídico}

Ciertamente, la trascendencia de la interpretación de los derechos fundamentales no ha sido ignorada por los órganos encargados de llevar adelante tal tarea. La enunciación y virtual aplicación de determinados criterios de interpretación se refleja en la jurisprudencia de los tribunales constitucionales, cada vez que realizan su tarea diaria de «asignar» 0 «descubrir" los alcances, límites o restricciones a los cuales se encuentran sujetos los derechos. ${ }^{11}$

Ello se debe, como expone Gregorio Peces Barba, a que "los derechos aparecen normalmente enumerados en las constituciones, sin que se especifique cual es su significado concreto". Corresponde, ciertamente, a los operadores jurídicos esa asignación. "En primer lugar al legislador, pero a continuación a los restantes sujetos que utilizan el Derecho. Los derechos fundamentales, al estar situados en los eslabones superiores del ordenamiento, al constituirse en normas básicas materiales, necesitan para su concreción el paso por diferentes operadores que poco a poco van delimitando su significado. En este sentido, a la hora de dotar de significado a estas figuras, el papel de la interpretación es clave». ${ }^{12}$

Evidentemente, esa interpretación no se realiza por un prurito afán académico. Como señala Gustavo Zagrebelsky, «la interpretación jurídica es una actividad eminentemente práctica, en el sentido de que procede de casos prácticos y tiene como finalidad su resolución». ${ }^{13}$ En ese sentido, si las implicancias de su interpretación en la vida estatal han advertido la necesidad de prestar una atención especial a los criterios que se utilizan en la interpretación de los derechos, la interpretación misma termina convirtiéndose en un auténtico problema jurídico cuando con ella se zanjan dudas en torno a la descifración de los alcances y límites a los que están

11 Sobre si la interpretación es una operación destinada a «describir el significado de alguna cosa, o bien [...] decidir este significado", Cfr. Michel Troper, "Una teoria realista dell'interpretaziones, en: Materiali per una storia della cultura giuridica, Anno XXIX, $\mathrm{N}^{\circ}$ 2,1999, p. 473 y ss.

12 Gregorio Peces Barba, Curso de Derechos Fundamentales. Teoría General, Universidad Carlos III-BOE, Madrid, 1995, pp. 577-578.

13 Gustavo Zagrebelsky, "La Corte Constitucional y la interpretación de la Constitución» en: Antonio López Pina (cooordinador), División de poderes e interpretación. Hacia una teoría de la praxis constitucional, Editorial Tecnos, Madrid, 1987, p. 162. 
sometidos los derechos esenciales, es decir, cuando se esclarece los límites jurídicos a los cuales están sometidos los poderes públicos y los propios particulares en las relaciones inter privatos. ${ }^{14}$

De ahí que aun cuando la identificación de muchos criterios específicos de interpretación no haya estado asociada con el establecimiento de instrumentos procesales destinados a hacerlos efectivos, es evidente que su problemática adquiere toda su virtualidad en el seno de éstos. Los procesos constitucionales, así, terminan por convertirse en el escenario privilegiado donde se desenvuelve la interpretación de los derechos fundamentales. Y es que, cuando un Tribunal Constitucional o cualquier juez pretende protegerlos, debe proceder «en su actuación interpretadora a una definición de su contenido, resolviendo los conflictos que su observancia pueda implicar en cada caso concreto". ${ }^{15}$ De ahí que siguiendo a Rubio Llorente, puede decirse que la interpretación jurídica de los derechos fundamentales es, esencialmente, la «interpretación judicial de los derechos fundamentales». ${ }^{16}$

Desde luego, plantear como problema jurídico la interpretación de los derechos fundamentales presupone dar por descontado que las cláusulas que los reconocen constituyen derecho directamente aplicable, aunque no todas ellas puedan tener el mismo grado de eficacia. Precisamente, es de ese carácter de derecho directamente aplicable y, por tanto, de sus exigencias de efectividad, de donde se deriva "de un modo diverso al de los preceptos legales normales, una interpretación no solo explicativa, sino rellenadora, que recibe no pocas veces la forma de un desciframiento o concretización». ${ }^{17}$ Por ello, como sostiene Christian Starck, solo cuando las cláusulas que reconocen derechos constituyen derecho directamente aplicable, «la definición de los derechos fundamentales constituye el primer paso para una efectiva tutela de éstosw. ${ }^{18}$

14 Cfr. Francisco Rubio Llorente, La forma del Poder, CEPC, Madrid, 1997, pp. 615-616.

15 Juan José Solazábal Echavarría, "Los derechos fundamentales en la Constitución española», en: Revista de Estudios Políticos, N 105, Madrid, 1999, p. 27.

16 Francisco Rubio Llorente, La forma del poder, op. cit., pp. 584-585.

17 Ernest Bockenforde, "Teoría e interpretación de los derechos fundamentales» en su libro Escritos sobre derechos fundamentales, Nomos Verlagsgesellschaft, Baden-Baden, 1993, p. 44 .

18 Christian Starck, «Il diritti fondamentali nel Grundgesetz della Repubblica Federale di Germania", en: Giurisprudenza Costituzionale, Fasc. 3, Giuffré editore, Milano, 1992, p. 2521. 


\section{Interpretación de los derechos fundamentales e interpretación de los derechos humanos}

Por cierto, basado en la distinción convencional entre «derechos fundamentales", como derechos reconocidos en la Constitución, y «derechos humanos", como atributos subjetivos reconocidos en los tratados, ${ }^{19}$ y en la existencia de instancias supranacionales encargadas de la tutela de estos últimos, es usual diferenciar los criterios de interpretación de los derechos humanos de los que corresponden a los derechos fundamentales. ${ }^{20}$

Es común observar que los criterios de interpretación en materia de derechos humanos sean rescatados e instrumentalizados por los tribunales internacionales instituidos para su defensa, y que éstos no sean invocados por los órganos de la jurisdicción interna. Ello no deja de ser curioso, sobre todo si es que se tiene en cuenta que la recepción constitucional del derecho internacional de los derechos humanos ha generado que los operadores jurídicos tengan que obrar en un auténtico «jardín de derechos». ${ }^{21}$ Y ese fenómeno es posible de observarse no solo en aquellos ordenamientos donde a los tratados se les ha dotado de rango constitucional, sino también en aquellos, como Perú, Colombia, España o Portugal, donde constitucionalmente se ha previsto que tales tratados sirvan de pautas interpretativas aptas para descifrar el contenido, los alcances y límites de los derechos y libertades reconocidos por la Constitución.

Según algunos, la singularidad de las pautas de interpretación de los derechos humanos obedece a la naturaleza y peculiaridad de los instrumentos internacionales sobre derechos humanos. Javier Ciurlizza, por ejemplo, ha aludido a la necesidad de tener en cuenta la fuente en la que se produce el reconocimiento de un derecho humano, esto es, su naturaleza y los parámetros que en el ámbito del derecho internacional se maneja

19 Según Robert Alexy, «La institucionalización de los derechos humanos en el Estado constitucional democrático», en: Derechos y Libertades, N8, Madrid, 2000, p. 37, «Se puede hablar [...] también de derechos fundamentales en lugar de derechos humanos".

20 Sobre las diferencias entre la expresión derechos humanos y derechos fundamentales, existe una amplia bibliografía. En particular, Gianluigi Palombella, «Derechos fundamentales: argumentos para una teoríam, en: Doxa, $\mathrm{N}^{\circ} 22,1999$, pp. 525-532. Entre nosotros, Reynaldo Bustamante Alarcón, "Positivismo jurídico y derechos humanos”, en: Ius et Veritas, $\mathrm{N}^{\circ} 24,2001$, p. 126 y ss.

21 La expresión es de Alessandro Pace, "Metodi interpretativi e costituzionalismo", en: Quaderni Costituzionali, $\mathrm{N}^{\circ} 1,2001$, pp. 35-36. 
para su interpretación. ${ }^{22}$ Desde esta perspectiva, al interpretárselos, debería tenerse en cuenta el compromiso internacional de los estados contratantes por respetar, en la jurisdicción interna, los derechos esenciales de los seres humanos $y$, en particular, las obligaciones derivadas de ese compromiso; esto es, la de respetar, proteger y garantizar, real y efectivamente, los derechos reconocidos en los tratados, de acuerdo con el sentido, la naturaleza y el alcance otorgado a los mismos. ${ }^{23}$

En cualquier caso, se tratan de criterios de interpretación que son de reciente data y «algunas de ellas no tienen una elaboración definitiva. Antes bien, son propuestas no concluidas ni cerradas, aunque en buena medida ya han sido recepcionados por órganos de la jurisdicción internacional y por la cultura jurídica contemporánea». ${ }^{24}$ Entre estos ${ }^{25}$ cabe mencionar a los principios de "progresividad", «interacción", "promoción", «universalidad», «indivisibilidad», «irreversibilidad» de los derechos humanos y la interpretación de acuerdo con el objeto y fin del tratado, ${ }^{26}$ que en esta oportunidad no serán desarrollados.

22 Javier Ciurlizza, «La interpretación en el derecho internacional de los derechos humanos: el caso de la función consultiva de la Corte Interamericana», en: Agenda Internacional, $\mathrm{N}^{\circ} 4$, Lima, 1995, pp. 92-93.

23 Jorge Carmona Tinoco, «La aplicación judicial de los tratados sobre derechos humanos» en: AA.VV., Derecho Internacional de los Derechos Humanos, Memoria del VII Congreso Iberoamericano de Derecho Constitucional, UNAM, México, 2002, p. 186.

24 Néstor Pedro Sagüés, «La interpretación de los derechos humanos en las jurisdicciones nacional e internacional", en: AA. VV., Derechos humanos y Constitución en Iberoamérica, [José Palomino Manchego y José Carlos Remotti (Coordinadores)], Editorial Grigley, Lima, 2002, pp. 35-36.

25 Además del trabajo antes citado de Néstor Sagüés, Cfr. Germán Bidart Campos, La interpretación de los derechos humanos, Editorial Ediar, Buenos Aires, 1994.

26 Por cierto, no son los únicos. Existen otros, que si bien aún no han calado en la jurisprudencia de la Corte Interamericana de Derechos Humanos, los aplican otros tribunales similares, como el Tribunal Europeo de Derechos Humanos o la Corte de Justicia de la Comunidad Europea. Es el caso, entre otros, del denominado criterio de "las tradiciones constitucionales comunes", esto es, el criterio según el cual las disposiciones de los tratados sobre derechos humanos, deben ser interpretadas de conformidad con el Derecho Constitucional Común Europeo, que, desde luego, no se identifica con el concepto de constitución formal de cada uno de los Estados partes. Sobre el tema, véase la ponencia de Luigi Cozzolino, "Le tradizioni costituzionali comuni nella giurisprudenza della Corte di Giustizia delle Comunitá europees, al Congreso La Corte Costituzionale e le corti d'Europa, realizado en Catanzaro, Italia, entre el 31 de mayo y el 1 de junio de 2002, versión mecanografiada. Antonio Ruggeri, «Tradizioni costituzionali comuni e controlimiti, tra teoria delle fonti e 


\section{Los criterios de interpretación de los derechos fundamentales ${ }^{27}$}

Diversos son los criterios de interpretación de los derechos fundamentales y, pese a su empleo frecuente, no siempre es fácil determinar sus alcances. A veces, porque su formulación ha sufrido modificaciones ( $v$. gr. el criterio de las libertades preferidas) y, en otras, porque sus alcances suelen entremezclarse entre sí (v. gr. el pro homine con el principio de la mayor protección). Aún así, en lo que sigue, se tratará de describir cada uno de ellos, especificando sus alcances.

\subsection{Principio pro homine}

Uno de los criterios frecuentemente utilizados por los tribunales constitucionales ( $y$ por cierto, también por los tribunales internacionales de derechos humanos) es el pro homine. Se trata de un "[...] criterio hermenéutico que informa todo el derecho de los derechos humanos, en virtud del cual se debe acudir a la norma más amplia, o a la interpretación más extensiva, cuando se trata de reconocer derechos protegidos e, inversamente, a la norma o a la interpretación más restringida cuando se trata de establecer restricciones permanentes al ejercicio de los derechos o

teoria dell'interpretazionem, en: Diritto Pubblico Comparato, ed Europeo, 2003-I, p. 102 y ss. Sin perjuicio de la ulterior bibliografía que se cite, Diego Rodríguez Pinzón, Claudia Martín y Tomás Ojea, La dimensión internacional de los derechos humanos, BID, Washington, 1999, p. 54 y ss. y Antonio Cançado Trindade, El derecho Internacional de los Derechos Humanos en el siglo XXI, Editorial Jurídica de Chile, Santiago de Chile, 2001, p. 35 .

27 Cabe precisar que cuando aquí se alude a las pautas de interpretación de los «derechos fundamentales", con ello no se está haciendo excluyendo a los derechos "sociales", "económicos", "culturales" o "políticos", que formalmente no tienen tal condición en la Carta de 1993. En realidad, en nuestra actual Constitución la expresión «derechos fundamentales" no tiene relevancia jurídica, sea esta sustancial o procesal. Por un lado, pues no todos los proclamados como "fundamentales» lo son por su estructura y finalidad; y, de otro, no todos los que están en el Capítulo I del Título I de la Constitución son «derechos» (piénsese, por ejemplo, en la "legítima defensa" distinta, desde luego, del derecho de defensa, o en la constitucionalización de la "asociación", como persona jurídica, distinta del «derecho de asociación»); ni, en fin, allí se encuentran "todos» los derechos fundamentales. Por ello, se puede sostener, parafraseando a Antonino Spadaro, que la Constitución de 1993 ha hecho un uso "promiscuo e indiscriminado" de la denominación "derechos fundamentales" [A. Spadaro, "Il problema del "fondamento" dei diritti fondamentali» en: Diritto e Societá, N³, 1991, p. 453]. 
a su suspensión extraordinaria». ${ }^{28}$ La pauta interpretativa en referencia, como señala Sagüés, tiene dos variantes:

\section{1.1. Preferencia interpretativa}

Por un lado, lo que Sagüés denomina una «directriz de preferencia interpretativa", esto es, el intérprete de los derechos ha de buscar la interpretación que más optimice un derecho constitucional. Tal directriz de preferencia interpretativa, a su vez, comprende:

(a). El principio favor libertatis, que "postula entender al precepto normativo en el sentido más propicio a la libertad en juego", ${ }^{29}$ en un doble sentido. A saber:

(i) Las limitaciones que mediante ley se establezcan a los derechos fundamentales no deberán ser interpretadas extensivamente, sino, siempre de modo restrictivo.

ii) Su correlato, es decir, que el operador deba interpretar la norma de manera que mejor optimice su ejercicio, pues cada disposición constitucional, como señala Häberle, «está dirigida a la realidad» y, en ese sentido, "está solícita de una interpretación orientada a la efectividad, a la vigencia práctica, material». Desde esta perspectiva, en palabras del Tribunal Constitucional Federal Alemán [BverfGE, 6, 55 (72)]..$^{30}$ "incumbe a la jurisprudencia constitucional descubrir la diferente función de una norma constitucional y en particular de un derecho fundamental. Y al respecto se dará preferencia a la interpretación que más fuertemente despliegue la eficacia jurídica de la normam. ${ }^{31}$

28 Mónica Pinto, «El principio pro homine. Criterios de hermenéutica y pautas para la regulación de los derechos humanos» en: Martín Abregú y Christian Courtis (Compiladores), La aplicación de los tratados sobre derechos humanos por los tribunales locales, Editores del Puerto, Buenos Aires, 1997, p. 163.

29 Néstor Pedro Sagüés, "La interpretación de los derechos humanos en las jurisdicciones nacional e internacional", en: AA. VV., Derechos humanos y Constitución en Iberoamérica, [José Palomino Manchego y José Carlos Remotti (Coordinadores)], op. cit., p. 36.

30 Peter Häberle, La libertad fundamental en el Estado Constitucional, op. cit., p. 328 y 263 (nota 146), respectivamente.

$31 \mathrm{Cfr}$. entre la jurisprudencia del Tribunal Constitucional peruano, la recaída en el Exp. N 0200-2002-AA/TC, Fund. Jur. N 4; la STC 795-2002-AA/TC, Fund. Jur. N ${ }^{\circ}$ 1. Con referencia expresa al favor libertatis y las exigencias derivadas de dicho criterio en materia de prisión preventiva, Cf. la STC 1091-2002-HC/TC, Fund. Jur. Nº 12. 
(b). En segundo lugar, el "principio de protección a las víctimas" o, como alude Bidart Campos, el principio favor debilis, es decir «que en la interpretación de situaciones que comprometen derechos en conflicto es menester considerar especialmente a la parte que, en su relación con la otra, se halla situada en inferioridad de condiciones $o$, dicho negativamente, no se encuentra realmente en pie de igualdad con la otram. ${ }^{32}$

\section{1.2. Preferencia de normas}

Pero, de otro lado, el principio pro homine también comprende una "directriz de preferencia de normas", es decir, que ante un caso a debatir, el juez [...] tendrá que aplicar la norma más favorable a la persona, con independencia de su nivel jurídicom. ${ }^{33}$ Este principio de interpretación de los derechos fundamentales se encuentra recogido en el inciso b) del artículo $29^{\circ}$ de la Convención Americana de Derechos Humanos, que, como recuerda el artículo $55^{\circ}$ de la Constitución, forma parte del derecho nacional. Establece dicho precepto que: "Ninguna disposición de la presente Convención puede ser interpretada en el sentido de: [...] b). Limitar el goce y ejercicio de cualquier derecho o libertad que pueda estar reconocido de acuerdo con las leyes de cualquiera de los Estados Partes o de acuerdo con otra Convención en que sea parte uno de dichos Estados". ${ }^{34}$

En el Derecho Internacional de los Derechos Humanos se ha acogido también dicha pauta con un matiz singular. Según algunos, con el principio en referencia se expresaría la superioridad de las disposiciones que

32 Germán Bidart Campos, «Las fuentes del Derecho Constitucional y el principio pro homine», en: Germán Bidart Campos y Andrés Gil Domínguez (Coordinadores), El Derecho Constitucional del Siglo XXI: Diagnóstico y perspectivas, op. cit., p. 18. Según Bidart, variantes del pro bomine lo constituirían los principios indubio pro operario y aquellos que están relacionados con el consumo y uso de bienes y servicios o los sujetos débiles en los contratos de adhesión.

33 Néstor Pedro Saguiés, «La interpretación de los derechos humanos en las jurisdicciones nacional e internacional», en: AA. VV., Derechos humanos y Constitución en Iberoamérica, [José Palomino Manchego y José Carlos Remotti (Coordinadores)], op. cit., p. 37.

34 Este principio comprendería, a su vez, lo que en sede del Derecho de los Derechos Humanos, se ha venido en denominar "principio de la primacía de la norma más favorable a la víctima", que a juicio de Antonio Cancado Trindade [El derecho Internacional de los Derechos Humanos en el siglo XXI, Editorial Jurídica de Chile, Santiago de Chile, 2001, p. 39] se debe observar cada vez que exista una dualidad de procedimientos para el juzgamiento de violaciones de derechos humanos. 
reconocen derechos humanos frente a las normas que regulan el ejercicio del Poder. A juicio de Carlos Ayala Corao, ${ }^{35}$ "cada vez que una norma de derechos se encuentre en conflicto con una norma de poder, el caso debe ser resuelto escogiendo favorablemente la norma sobre el derecho. En este sentido, las normas sobre derechos son superiores a las normas sobre poder ubicadas en un mismo plano, pues las primeras orientan en definitiva la actuación de los órganos del poder público. Así el Derecho democrático debe construirse e interpretarse teniendo por principio y fin último, a los derechos de la persona humana».

En cierto modo, en su vertiente de preferencia de normas, tal criterio fue aplicado por el Tribunal Constitucional en la sentencia expedida en el Exp. $\mathrm{N}^{\circ}$ 1091-2002-HC/TC. Entre otras cosas, se discutía si cabía cuestionar, a través del hábeas corpus, la detención judicial preventiva. Las instancias judiciales ordinarias rechazaron la pretensión in limine, al considerar que en el caso era de aplicación el inciso b) del artículo $16^{\circ} \mathrm{de} \mathrm{la}$ Ley $\mathrm{N}^{\circ} 25398$, según el cual: «No procede la acción de hábeas corpus: [...] b) Cuando la detención que motiva el recurso ha sido ordenada por juez competente dentro de un proceso regular». No obstante, el Tribunal Constitucional reparó que al lado de dicha disposición legal, también era aplicable en el caso el artículo 7.6 de la Convención Americana de Derechos Humanos, a tenor de la cual es un derecho de toda persona privada de su libertad "a recurrir ante un juez o tribunal competente, a fin de que este decida, sin demora, sobre la legalidad de su arresto o detención y ordene su libertad si el arresto o su detención fueran ilegales». Aunque explícitamente no lo afirmara, al resolver el problema acerca de su competencia o no para pronunciarse sobre el fondo de la cuestión, el Tribunal aplicó la disposición de la Convención Americana de Derechos, pues ésta optimizaba de mejor modo el derecho de acceso a la justicia.

\subsubsection{Constitución de 1993 y el principio pro homine}

El principio pro homine, en diversas de sus concretizaciones, se encuentra constitucionalizado. En algunos casos, con carácter general, esto es, como un criterio válido para interpretar cualesquiera de los derechos fundamentales. En otros, a propósito de determinados derechos constitucionales, como enseguida veremos.

35 Carlos Ayala Corao, «El derecho de los derechos humanos», en: Lecturas constitucionales andinas, No 3, CAJ, Lima, 1994, pp. 67-68. 


\section{a) La interpretación restrictiva de los derechos fundamentales}

Con carácter general, una variante del pro homine, en su versión de "directriz de preferencia interpretativa", es el que se encuentra constitucionalizado en el inciso 9) del artículo $139^{\circ}$ de la Constitución. Según dicho precepto uno de los principios que deberá de observarse en el ejercicio de la función jurisdiccional es «el principio de inaplicabilidad por analogía [...] de las normas que restrinjan derechos».

Desde una perspectiva general, a través de dicha cláusula se afirma que los derechos no pueden considerarse como exento de límites, esto es, con carácter absoluto, sino susceptibles de ser restringidos. No obstante, el criterio en cuestión impone que tales restricciones, además de estar constitucionalmente justificadas y legalmente configuradas, deban interpretarse siempre de forma restrictiva, precisamente por la fuerza expansiva de los derechos fundamentales, ${ }^{36}$ es decir, en el sentido de permitir el mejor ejercicio del derecho dentro de los límites a los que se les ha sujeto. ${ }^{37}$

b) Indubio pro operario y derechos laborales

Otra manifestación del principio pro homine, también en su variante de «directriz de preferencia interpretativa", es el indubio pro operario, esto es, el principio según el cual ha de optarse por la «interpretación favorable al trabajador en caso de duda insalvable sobre el sentido de una norma", recogido en el inciso 3) del artículo 26 de la Constitución de 1993.

Este criterio específico de interpretación opera sobre una clase de derechos constitucionales; en concreto, sobre los denominados derechos laborales. Por virtud de él, se exige del operador jurídico que, en aquellos casos en los que de una disposición se desprendan cuando menos dos normas, esto es, dos sentidos interpretativos, ${ }^{38}$ este debe aplicar la dispo-

36 Cfr. Pablo Pérez Tremps, "La interpretación de los derechos fundamentales", en: Estudios de Derecho Constitucional. Homenaje al profesor doctor don Joaquín García Morillo, Luis López Guerra (coordinador), Tirant lo Blanch, Valencia, 2001, p. 126. Edgar Carpio y Carlos Mesía, El amparo y los derechos fundamentales, Academia de la Magistratura, Lima, 2002, p. 34 y ss.

37 Cfr. entre la abundante y desigual jurisprudencia, la modélica sentencia recaída en el Exp. $N^{\circ} 1003-1998-A A / T C$, Fund. Jur. $N^{\circ} 3$.

38 Sobre la distinción entre "disposición», como enunciado lingüístico perteneciente a una fuente formal del derecho, y "norma», como sentido interpretativo de aquel, $\mathrm{Cfr}$. Riccardo Guastini, "Disposizione e norme", en: Giurisprudenza Costituzionale, $\mathrm{N}^{\circ} 3$, 1989 , p. 3 y ss. Asimismo, Cfr. La sentencia expedida por el Tribunal Constitucional en el caso de la legislación antiterrorista (Exp. N010-2002-AI/TC). 
sición en el sentido interpretativo que más favorece al trabajador. La aplicación de este criterio interpretativo en materia laboral, pues, presupone la existencia, al menos, de una disposición (legal o constitucional), a la cual quepa adscribir, a su vez, cuando menos dos sentidos interpretativos divergentes. En tales supuestos, el inciso 3 ) del artículo $26^{\circ}$ de la Constitución exige que el juez de los derechos laborales opte por aplicar la disposición legal en el sentido interpretativo que más favorece al trabajador.

Por otro lado, no se puede perder de vista que el indubio pro operario no solo se sustenta en la variante del pro homine entendida como «directriz de preferencia interpretativa", sino, también en su variante preferencia de normas. ${ }^{39}$ Aún más, incluso puede decirse que, más allá de la intención del constituyente de 1993 de mediatizar el principio en referencia, cabe entender la existencia de un favor debilis. Es decir, una exigencia de interpretación y/o aplicación de disposición legal en el sentido que más favorezca a los trabajadores, tradicionalmente considerados como la parte más débil en la relación de trabajo. ${ }^{40}$

\section{c. Principio pro actione y derecho a la tutela jurisdiccional efectiva}

Aunque formalmente no se encuentre expresado en una disposición constitucional, el principio pro actione también constituye una concretización del pro homine en el ámbito procesal y, en particular, con aquellos atributos que forman parte del derecho a la tutela jurisdiccional efectiva. ${ }^{41}$ Según Bidart Campos, tal manifestación del pro homine en el ámbito procesal facilita, hace accesible, y no obstruye, un «adecuado y recíproco sistema garantista, más la legitimación holgada de quien a él acude en procura de justicia». ${ }^{42}$

39 Cfr. la STC recaída en el Exp. No 2532-2002-AA/TC.

40 Sobre el tema, Cfr. Javier Neves Mujica, Introducción al Derecho Laboral, Fondo Editorial de la PUCP, Lima, 2000, p. 123 y ss, donde se destaca el carácter absurdo de haberse condicionado tal aplicación de la ley más favorable a la existencia de una "duda insalvable».

41 Cfr. sobre el particular, entre otras, la STC recaída en el Exp. N 1003-1998-AA/ $\mathrm{TC}$, donde se apela a dicho principio para flexibilizar las exigencias derivadas de la obligatoriedad de agotar la vía administrativa como condición de la acción.

42 Germán Bidart Campos, "Las fuentes del Derecho Constitucional y el principio pro homine», en: Germán Bidart Campos y Andrés Gil Domínguez (Coordinadores), El Derecho Constitucional del Siglo XXI: Diagnóstico y perspectivas, Ediar, Buenos Aires, 2000, p. 17. 
Tal sub-principio, por cierto, no opera con la misma intensidad sobre todos los derechos que forman parte de la tutela jurisdiccional. Así, por ejemplo, en relación con el derecho de acceso a la justicia, este exige del intérprete que las condiciones o las limitaciones que la ley pueda establecer deban ser interpretadas de manera tal que se optimice al mayor grado la efectividad del derecho. Así, por ejemplo, el Tribunal Constitucional ha llamado la atención exigiendo que las normas que limitan el derecho de acceso a la justicia (las llamadas "condiciones de la acción", como la obligatoriedad de agotar la vía administrativa) deban ser interpretadas "en sentido favorable para posibilitar el acceso a la tutela jurisdiccional $y$, consiguientemente, con exclusión de toda opción interpretativa que sea contraria a ese propósito [...]". A juicio del Tribunal, una interpretación como la que venía haciendo con anterioridad (en el sentido de "ocasionar la caducidad y así impedir el ejercicio del derecho a la tutela judicial») «no resulta acorde con el principio pro homine y pro libertatis de la interpretación constitucional, según los cuales, ante eventuales diferentes interpretaciones de un dispositivo legal, se debe optar por aquella que conduzca a una mejor protección de los derechos fundamentales, descartando así las que restrinjan o limiten su ejercicion. ${ }^{43}$

En otra oportunidad, destacó que «el derecho de obtener una sentencia que se pronuncie sobre una pretensión es una manifestación del derecho a la tutela judicial y, como tal, si bien exige que el justiciable previamente satisfaga las condiciones de la acción que la ley establece, no puede perderse de vista que ésta debe ser interpretada y aplicada de tal forma que se haga efectivo el derecho de acción o derecho de acceso a la jurisdicción». ${ }^{44}$

No obstante, tal especial intensidad del pro actione varía si se trata de otros derechos constitucionales procesales, como puede ser, por ejemplo, el derecho de acceso a los recursos. ${ }^{45}$ Según Requejo Pagés, ello se debe a que mientras con el primero, su no aplicación puede «eliminar el derecho a someter el caso a un Juez», en el segundo, en cambio, solo se privaría «de

43 STC N 1103-1998-AA/TC, Fund. Jur. N³, «e» y «d». Asimismo, la STC 0499-2002-AA/TC, Fund. Jur. $N^{\circ} 1$.

44 STC N 112-2002-AA/TC, Fund. Jur. $\mathrm{N}^{\circ} 3$.

45 Como derivado de los principios de proporcionalidad y seguridad jurídica, es conceptualizado el principio en referencia por Enrique García Pons, «Aporía del principio pro actione en el ámbito temporal del proceso debido: comentario a la sentencia del Tribunal Constitucional 136/1997", en: La Ley, 6, Madrid, 1997, p. 1698. 
la revisión de la respuesta judicial ya pronunciada en la sentencia de instancia", de manera que ya se habría "satisfecho el núcleo fundamental del derecho a obtener la tutela judicial efectiva». ${ }^{46}$ Aún así, el Tribunal peruano ha sido especialmente sensible en la aplicación de dicho criterio, tratándose del derecho de acceso a los recursos. Por ejemplo, en un caso, en el que la Corte Suprema declaró la inadmisibilidad del recurso de casación, pues no todos los impugnantes habían pagado la tasa judicial, el Tribunal declaró la nulidad de dicha resolución y ordenó admitir el recurso, por considerar "que una interpretación pro actione del derecho constitucional de acceso a los recursos no admite que, tratándose de varios codemandantes, si solo uno de ellos hubiera pagado la tasa judicial correspondiente, y no así los otros, se tenga que declarar inadmisible el recurso de casación formulado [...]». A su juicio, «a falta de una norma como la $2^{\circ}$ Disposición Complementaria y Final de la Resolución Administrativa $\mathrm{N}^{\circ}$ 1074-CME-PJ, las autoridades judiciales emplazadas debieron cubrir la laguna realizando una interpretación extensiva de las normas del Código Procesal Civil, de conformidad con los derechos constitucionales, no en el sentido de obstaculizar su ejercicio, sino en la perspectiva de optimizarlo, a fin de que, en el caso, no se produzca una denegación de justicia». ${ }^{47}$

\subsection{Posición preferente de los derechos fundamentales (preferred freedoms)}

Los derechos fundamentales gozan de una posición preferente en el ordenamiento jurídico. Desde una perspectiva estrictamente formal, ello se deriva de la ubicación de los derechos dentro del texto Constitucional $\mathrm{y}$, desde una perspectiva material, de la instrumentalidad del ordenamiento estatal para con su respeto. Dice, en efecto, el artículo $1^{\circ} \mathrm{de}$ la Constitución de 1993 que «la defensa de la persona humana y el respeto de su dignidad son el fin supremo de la sociedad y del Estado». Como anota Pérez Tremps, los derechos fundamentales son el «reflejo jurídico de los valores éticos de libertad y dignidad básicos en la sociedad democráti-

46Juan Luis Requejo Pages, «El derecho de acceso a los recursos», en: AA.VV., La Constitución y la práctica del Derecho (Dirigido por Manuel Aragón y Julián MartínezSimancas), Aranzadi, Navarra, 1998, p. 417.

47 STC recaída en el Exp. N³58-2001-AA/TC. 
ca». ${ }^{48}$ En esa medida, imponen la exigencia de que todo el ordenamiento jurídico deba ser interpretado de conformidad con los derechos fundamentales, de manera que, como afirmara Herbert Kruger, si «antes los derechos fundamentales valían en el ámbito de la ley, hoy las leyes valen solo en el ámbito de los derechos fundamentales». ${ }^{49}$

Sin embargo, los alcances del principio no son del todo claros, pues ha sido objeto de diversos desarrollos. Según algunos, los derechos fundamentales, en su totalidad, deberían prevalecer siempre sobre los bienes o aspiraciones colectivas, precisamente en atención a su posición preferente en el ordenamiento jurídico. ${ }^{50}$ Para otros, como Carlos Ayala Corao, la posición preferida de los derechos no significa asumir una posición individualista o liberal, que rechace las regulaciones o limitaciones legales a las cuales están sometidos los derechos sin que ello desvirtúe su contenido. Significa que «cuando estén en conflicto en un mismo plano, normas sobre derechos (humanos y/o constitucionales) y normas sobre poder, la controversia debe resolverse acogiendo la norma contentiva de derechos como privilegiada en rangon. ${ }^{51}$

Según otros, con tal principio se aludiría a la existencia de algunos derechos fundamentales axiológicamente más valiosos que otros, de modo que en un supuesto de conflicto entre ellos, el juez debería optar por proteger al de mayor valor [así, por ejemplo, la libertad de expresión sobre el derecho a la intimidad; las libertades individuales sobre los derechos sociales, etc]. Un decidido partidario de esta tesis lo fue Miguel Angel Ekmedjian en Argentina, para quien entre los derechos fundamentales existiría un orden jerárquico, de modo que en caso de colisión entre derechos, la solución pasa por preferir aquellas que tendrían una jerarquía superior. $^{52}$

48 Pablo Pérez Tremps, «La interpretación de los derechos fundamentales», en: Estudios de Derecho Constitucional, op. cit., p. 122.

49 Herbert Kruger, «El derecho constitucional alemán en la mitad del siglo XIX y su desenvolvimiento hasta nuestros días", en: AA.VV., El constitucionalismo a mediados del siglo XIX, T. 1, UNAM, México, 1957, p. 3 y ss.

50 Christian Guzmán Napurí, «El principio de preferencia por los derechos fundamentales: un intento de fundamentación lógica», en: Revista Jurídica del Perú, $\mathrm{N}^{\circ} 27$, Lima, 2001, p. 1 y ss.

51 Carlos Ayala Corao, «El derecho de los derechos humanos», en: Lecturas constitucionales andinas, $\mathrm{N}^{\circ} 3$, CAJ, Lima, 1994, p. 68.

$52 \mathrm{Cfr}$. Miguel Angel Ekmekjian, «El valor dignidad y la teoría del orden jerárquico de los derechos individuales», en: Germán Bidart Campos y Andrés Gil Domínguez, Los 
En el derecho constitucional norteamericano, donde surgió la doctrina de la preferred positions, tampoco la aplicación de este criterio interpretativo ha tenido un desarrollo uniforme. ${ }^{53}$ En las primeras décadas del siglo XX, a través de ella la Corte Suprema consideró que los derechos fundamentales no podían ser limitados con el objeto de satisfacer bienes colectivos. Así se pronunció, por ejemplo, en el caso Lochner v. New York, resuelto en 1905, en la que se declaró inconstitucional una ley que limitaba la jornada laboral en las panaderías a diez horas diarias y sesenta horas semanales, privilegiándose de ese modo la libertad contractual y el derecho de propiedad. ${ }^{54}$

Con posterioridad, y tras dejarse atrás esa tendencia conservadora, bajo el canon de libertades preferidas se ha exigido que las limitaciones a los derechos con esas características (en particular, la libertad de expresión o el derecho de igualdad) sean sometidas a un control especialmente intenso. ${ }^{55}$ Ya esa doctrina pudo vislumbrarse en el caso Schenck v. United States (1919), en la que la Corte Suprema, a través de Oliver Wendel Holmes, sostuvo que las restricciones a la libertad de prensa, consideradas como el bastión natural de las libertades preferidas, solo podían limitarse si es que existía un "peligro claro y presente» que las justificase. En palabras del Chief Justice Oliver Wendell Holmes: «La cuestión en cada caso es si las palabras usadas lo son en tales circunstancias, y son de tal natura-

valores en la Constitución argentina, op. cit., p. 9 y ss. Adrián R. Rentería, "Censura previa y teoría del orden jerárquicom, en: El Derecho, de 10 de junio de 1992, pp. 2-3. Una exposición breve y lúcida de esta tesis en: Juan Cianciardo, El conflictivismo en los derechos fundamentales, EUNSA, Pamplona, 2000, p. 107 y ss.

$53 \mathrm{Cfr}$. además de la bibliografía que se cite Gino Scaccia, Gli strumenti della ragionevolezza nel giudizio costituzionale, Giuffré editore, Milano, 2000, p. 315 y ss.

54 Cfr. Reynaldo Bustamante Alarcón, "Positivismo jurídico y derechos humanos. Algunos problemas generados por una neutralidad valorativa en una teoría sobre derechos humanos", en: Ius et Veritas, $\mathrm{N}^{\circ} 24$, Lima, 2003, p. 136 y ss.

55 Cabe destacarse que esta apelación, en términos generales, a criterios de razonabilidad está en el corazón mismo del common law, donde el derecho evoluciona a golpe de casos. Como tal, se remonta a la experiencia inglesa y ya era posible de encontrarse formulada en los antecedentes de la creación de la judicial review. Cf. al efecto, el clásico trabajo de Edward Corwin, L'idea di legge superiore e il diritto costituzionale americano, Neri Pozza Editore, Venecia, 1962 (?), p. 78 y ss, donde alude a referencias sobre el Case Bonham, de 1607, y Rowles c. Mason, de 1612, ambos redactados por Edward Coke. 
leza, como para crear el peligro claro y presente, que acarrearán los males substanciales que el congreso tiene derecho a impedirm. ${ }^{56}$

Sin embargo, el antecedente más cercano sobre la posición preferente de los derechos reconocidos en la Primera Enmienda comúnmente suele identificarse en la nota de pie de página $\mathrm{N}^{\circ} 4$ del voto del Juez $\mathrm{H}$. F. Stone en el caso United States v. Carolene Products Co, resuelto en 1938: "Puede haber un margen más reducido de actuación de la presunción de constitucionalidad cuando la legislación parece caer, a primera vista, dentro de una prohibición específica de la Constitución, tal como aquellas establecidas en las primeras diez enmiendas [...]. Resulta innecesario considerar ahora si la legislación que restringe aquellos procesos políticos de los que ordinariamente se espera que conlleven al rechazo de legislación indeseable haya de estar sometida a un escrutinio judicial más estricto bajo las prohibiciones generales de la enmienda decimocuarta de lo que están la mayor parte de otros tipos de legislación [...]. Tampoco es necesario que indaguemos si consideraciones análogas hacen parte del control de leyes dirigidas a minorías religiosas [...], nacionales [...] o étnicas particulares; si el prejuicio contra minorías discretas e insulares puede ser una condición especial, que tiende seriamente a limitar la operación de aquellos procesos políticos en los que ordinariamente se puede confiar para proteger a las minorías, y que pueden exigir, por ende, un examen judicial más profundom. ${ }^{57}$

Cuatros años después, la doctrina fue expresamente aceptada en el caso Jones v. the City of Opelika (1942): "La Primera Enmienda no se limita a salvaguardar la libertad de expresión y la libertad de religión frente a los intentos de suprimirlas discriminadamente. Por el contrario, la Constitución, en virtud de sus Enmiendas Primera y Decimotercera, las ha situado en una posición preferentem. ${ }^{58}$

Desde entonces, se entiende que la posición preferente de ciertos derechos fundamentales se refleja, en sus líneas generales, en la intensidad del control constitucional al que se somete cualquier actividad estatal

56 La Constitución de los Estados Unidos anotada con la jurisprudencia, T. II, Editorial Kraft, Buenos Aires, 1949, p. 20.

57 Citado por John Hart Ely, Democracia y desconfianza. Una teoría del control constitucional, Siglo del hombre editores, Bogotá, 1997, p. 100.

58 Citado por Santiago Sánchez González, La libertad de expresión, Marcial Pons, Madrid, 1992, p. 50. El trabajo clásico sobre la materia es de Robert B. Mckay, "The preference for freedom", en: New York University Law Review, N³4, 1959, p. 1182 y ss. 
limitadora de los derechos. ${ }^{59}$ Así, a diferencia de lo que sucede con los derechos económicos, donde solo se exige la realización de un simple reasonableness-test, y sobre los derechos fundamentales que no tienen la condición de libertades preferidas, que están sometidos a un substantialracionality-test, tratándose de las libertades preferidas, como la de la Primera y Decimocuarta Enmienda, éstas estarían sujetas a un stric-scrutinytest. ${ }^{60}$

Este escrutinio estricto se traduce, por un lado, en exigir una justificación de la actividad limitadora bajo el parámetro del principio de proporcionalidad en sentido estricto y en la inversión del principio de constitucionalidad de las leyes por la presunción, prima facie, de inconstitucionalidad. ${ }^{61}$ De esta manera, la carga justificatoria de la medida limitativa se entiende que corre por cuenta del Estado, quien está obligado a justificar debidamente que existe un «interés estatal urgente» (pressing public necessity)] y, de otro lado, el Tribunal se encuentra obligado a someter la justificación dada a un escrutinio judicial elevado.

El strict-scrutiny-test, pues es un standard de control más intenso que el de mera racionalidad, cuya no satisfacción termina por confirmar la presunción de inconstitucionalidad de la ley. ${ }^{62}$ Parafraseando lo que la Corte Suprema sostuvo en el caso United States v. Virginia, de 1996, sobre un tema de discriminación fundado en el sexo, en tales casos «[...] el

59 Cfr. sobre el tema, con amplias referencias, Alberto Vespaziani, «Il bilanciamento dei diritti nella cultura giuridica statunitense», en: Rivista di Diritto Pubblico, $\mathrm{N}^{\circ} 2,2001$, p. 457 y ss, así como el capítulo 1 de su libro Interpretazioni del bilanciamento dei diritti fondamentali, op. cit., pp. 2-73. Asimismo, Walter F. Carnota, "Los valores y las libertades preferidas" en: Germán Bidart Campos y Andrés Gil Domínguez (Coordinadores), Los valores en la Constitución argentina, op. cit., p. 165 y ss.

60 Cfr. entre nosotros, Eloy Espinosa-Saldaña, "Apuntes sobre el desarrollo de la jurisprudencia constitucional aplicable a los derechos fundamentales en los E.E.U.U.", en: Ius et Veritas, $\mathrm{N}^{\circ} 21$, Lima, 2001, p. 34 y ss.

61 Sobre el tema, resultan sumamente ilustrativas las páginas de Víctor Farreres Comellas, Justicia constitucional y democracia, CEPC, Madrid, 1997, p. 250 y ss. Cfr. además, Gerard J. Clark, «An introduction to constitutional interpretation», en: Suffolk University Law Review, Vol. 12, No 01, 2001, p. 21 y ss.

62 Tal escrutinio estricto se practica fundamentalmente en temas como desigualdad, utilización de las denominadas "cláusulas sospechosas» y la libertad de expresión. Sobre su utilización para el caso de las libertades preferidas y, en particular, sobre la libertad de expresión: Santiago Sánchez González, La libertad de expresión, Marcial Pons, Madrid, 1992 , p. 35 y ss. 
tribunal que realiza el examen debe determinar si la justificación alegada resulta ser «extremadamente persuasiva». La carga de la justificación es muy exigente y está en cabeza exclusiva del Estado. El Estado debe mostrar "al menos que la clasificación impugnada" tiende a satisfacer objetivos estatales importantes y que los medios discriminatorios utilizados tienen una relación sustancial con el logro de esos objetivos. La justificación debe ser genuina, no basada en hipótesis o inventada posteriormente en respuesta al litigio. Y no debe estar basada en generalizaciones excesivamente amplias acerca de los diferentes talentos, capacidades o preferencias de los hombres y las mujeres".

En definitiva, en el actual Derecho Constitucional norteamericano la posición preferente de los derechos fundamentales no se traduce en afirmar que al interior de la Constitución existe un orden jerarquizado de derechos fundamentales, de manera que en caso de conflictos, éstos deben resolverse bajo el método de la subsunción, ${ }^{63}$ sino en la idea de que existe un "grupo de derechos que no solo merecen una mayor protección por parte del gobierno, sino que además solo admiten una mínima intromisión de aquel en su regulación», que debe valorarse según el método de la ponderación. ${ }^{64} Y$ es que una solución como la primera, olvidaría que el reconocimiento de un derecho constitucional se realiza en un ordenamiento en el que coexisten, con el mismo rango formal, no solo otros derechos, sino también diversos bienes colectivos, de cuya optimización y efectividad depende el ejercicio pleno de aquellos. Como se verá más adelante, que los conflictos entre derechos fundamentales y bienes constitucionales no se resuelvan a través del método de la subsunción, sino mediante la ponderación, es consecuencia de que las cláusulas que reconocen derechos fundamentales no tienen la estructura propia de las denominadas "reglas", sino, la de los "principios", esto es, la de mandatos de optimización. ${ }^{65}$

63 Cabe, no obstante, advertir que desde la década de 1980, tras la recomposición del Tribunal Supremo con magistrados de tendencia conservadora, se asiste a una paulatina desustancialización de estas técnicas. Cfr. Tseming Yang, "Balancing interest and maximizing rights in environmental justices, en: Vermont Law Review, No 23, 2002, p. 529 y ss. Stephen Gottlieb, "Communities in the balance: Comments on Koch", en: Houston Law Review, Vol. 37, N³, 2000, p. 711 y ss.

64 Alberto Bianchi, Control de constitucionalidad. El proceso y la jurisdicción constitucionales, Editorial Abaco, Buenos Aires, 1992, p. 390.

65 Por cierto, la aplicación de esta técnica de control no ha sido ajena a serias críticas, no solo dentro de la misma Corte Suprema, sino también por la doctrina más autorizada. 
En la doctrina alemana, una asimilación del principio en el sentido de que entre los derechos existe un orden jerárquico ha sido considerada como «insostenible" [de una "generalización inadmisible» habla Klaus Stern]. ${ }^{66}$ De la misma opinión también ha sido el Tribunal Constitucional Federal Alemán que, en sus rasgos generales, ha efectuado una construcción semejante a la realizada por la Corte Suprema de los Estados Unidos.

A juicio de algunos, el carácter preferente de los derechos fundamentales solo se desenvuelve en la técnica de la ponderación. Se trata de una técnica que ya desde la década de 1950, fue rescatada por el Tribunal alemán y, en particular, en la sentencia dictada en el caso Luth, del 15 de enero de 1958, que a este respecto constituye uno de los leanding case de la jurisprudencia teutona. Se discutía, a través del Verfassungsbeschwerde, la validez de un mandato judicial que ordenaba que el señor Luth se abstuviera de expresar declaraciones en público dirigidas a incitar un boicot a la propalación de un film de inspiración antijudía. Al anular la sentencia, el Tribunal destacó que «la manifestación de la opinión es, pues, libre en cuanto tal, esto es, en su acepción meramente espiritual. Si ella, sin embargo, interfiriese con un bien jurídico protegido por otro derecho, cuya tutela amerita la preferencia en su conflicto con la libertad de opinión, tal interferencia no debe terminar considerándose legítima por el solo hecho de ser realizada a través de la manifestación del pensamiento. Se hace necesario, pues, un balanceamiento de los bienes. El derecho a la manifestación de la opinión debe ceder si el ejercicio de la libertad de opinión lesiona otros intereses dignos de protección y dotados de un rango supe-

Entre estos últimos, es el caso de Laurent Frantz ["The first amendment in the balance», en: Yale Law Journal, $N^{\circ} 71$, 1962, p. 1434, citado por David M. O’Brien, El derecho del público a la información. La suprema Corte de los E.U.A. y la primera enmienda, Publigrafics, México, 1983, p. 109], para quien, «si las argumentaciones empleadas para justificar el equilibrio son llevadas a su conclusión lógica, esto llevará a afirmar que la Constitución no contiene, ni siquiera es capaz de contener algo, llámese como se quiera, que sea incondicionalmente obligatorio [...] O sea, que cualquier cosa que según la Constitución no puede hacerse, se podrá hacer si el Congreso considera y la Corte está de acuerdo (o si no desea poner a un lado o desechar la opinión del Congreso) que los intereses que se articulen de este modo tienen más peso que los que resulten sacrificados. De este modo, todo el concepto de un gobierno de poderes limitados y de una Constitución escrita como instrumento para llegar a ese fin, se ven, al menos potencialmente, puestos en tela de juicion.

66 Klaus Stern, Derecho del Estado de la República Federal de Alemania, CEC, Madrid, 1984, p. 295. 
rior. Este predominante interés, debe ser evaluados teniendo en cuenta todas las circunstancias del caso" [BverfGE 7, 198, p. 208 y ss)]. ${ }^{67}$

Ni siquiera construcciones teóricas, por cuyos postulados, se habría podido inferir un genérico indubio pro libertatis, como podrían ser las teorías axiológicas o democrático-funcional de los derechos fundamentales, han postulado una jerarquía, en abstracto, entre derechos, o una superioridad de éstos sobre los bienes colectivos de relevancia constitucional. En este contexto, y de cara a lo afirmado por nuestro Tribunal Constitucional en algunas sentencias recientes, tal vez pueda ser útil una breve referencia a los postulados de los cuales parte la teoría democrático-funcional de los derechos.

Según ésta, los derechos deben entenderse «a partir de la función pública y política" que desempeñan en el Estado constitucional de derecho. Desde esta perspectiva, como expone Bockenforde, «en lugar preferente se encuentran los derechos fundamentales con referencias democráticas como la libertad de opinión, la libertad de prensa y la libertad de reunión y asociación", pues éstos alcanzan "su sentido y su principal significado como factores constitutivos de un libre proceso de producción democrática (esto es, que transcurre de abajo a arriba) del Estado [...] y de un proceso democrático de formación de la voluntad política». ${ }^{68}$ Desde esta perspectiva, en la condición de libertades preferidas se encontrarían los derechos de participación política y aquellas otras libertades esenciales para la formación del proceso democrático. ${ }^{69}$

Con ello se pretende superar la idea de los derechos fundamentales como derechos subjetivos y, por tanto, de libre disposición, para considerarlos «en su característica de componente de la colectividad y, por tanto, también en el interés público". Como afirma César Landa, mediante tal teoría «se pondera el carácter cívico de los derechos fundamentales como elementos constitutivos y participatorios de la democracia estatal». De

67 Citado por Jorg Luther, "Ragionevolezza e Verhaltnismabigkeit nella giurisprudenza costitucionale tedesca", en: Diritto e Societá, N 1-2, 1993, p. 313. En dicha sentencia se inauguraría la denominada Stufentheorie, esto es, la teoría de los grados, con exigencias de evaluación similares a los señalados por la Corte Suprema americana.

68 Bockenforde, "Teoría e interpretación de los derechos fundamentales", en: Escritos sobre derechos fundamentales, op. cit., p. 60.

69 Klaus Stern, «Riflessioni sull'interpretazione dei diritti fondamentali», op. cit., p. 235, con cita de la sentencia del Tribunal Constitucional Federal Alemán (BverwGE 14, $21(25)$. 
esta forma, el punto de partida, orientación y límites de los derechos fundamentales se encontrarían «en el proceso político democrático, que se convierte en el valor constituyente del contenido, ejercicio y de los contenidos de los derechos de la persona». ${ }^{70}$

No obstante, el Tribunal Constitucional Federal Alemán se ha resistido a aceptarla, incluso en relación con aquellos derechos más directamente comprometidos con el proceso político democrático. Y ello por la sencilla razón de que, como advierte Bockenforde, si es la función política del derecho lo que la hace una libertad preferida, el problema entonces es quién decide aquella función. En sus palabras, "con ello se convierte en decisiva la cuestión de quién y con qué criterios ha establecido en concreto la delimitación entre "político-apolítico", "público-privado». Dado que lo político carece de objeto delimitable, no está lejos el camino hacia el decisionismo políticamente motivadom. ${ }^{71}$

Por cierto, como se ha anticipado, una reciente sentencia del Tribunal Constitucional peruano pareciera haber rescatado una construcción semejante, a propósito de las libertades de expresión e información. Ha sostenido el Tribunal que tales libertades:

«[...] no solo constituyen una concreción del principio de dignidad del hombre y un complemento inescindible del derecho al libre desenvolvimiento de la personalidad. También se encuentran estrechamente vinculadas al principio democrático, en razón de que, mediante su ejercicio, se posibilita la formación, mantenimiento y garantía de una sociedad democrática, pues se permite la formación libre y racional de la opinión pública. Desde esa perspectiva, ambas libertades «tienen el carácter de derechos constitutivos por antonomasia para la democracia. Constituyen el fundamento jurídico de un proceso abierto de formación de la opinión y de la voluntad políticas, que hace posible la participación de todos y que es imprescindible para la referencia de la democracia a la libertad [...]).»

Por ello, tales libertades informativas son, al tiempo que derechos subjetivos, garantías institucionales del sistema democrático constitucional.

70 César Landa, "Teorías de los derechos fundamentales», en: Teoría del derecho procesal constitucional, Editorial Palestra, Lima, 2003, pp. 184-185.

71 Bockenforde, «Teoría e interpretación de los derechos fundamentales», op. cit., p. 62. 
Además, en tanto permiten la plena realización del sistema democrático, tienen la condición de libertades preferidas y, en particular, cuando su ejercicio permite el debate sobre la cosa pública» (cursivas nuestras). ${ }^{72}$

Tras de esa afirmación del Tribunal, sin embargo, no existe, en rigor, la aceptación de una teoría del orden jerárquico o, a su vez, la democráticofuncional de los derechos fundamentales, sino la aseveración de que en aquellos casos en los que con el ejercicio de la libertad de expresión se contribuye a la formación de la opinión pública libre, tal condición exige que cualquier restricción sobre tales libertades tenga que ser objeto de un stric scrutiny. No otro, en efecto, puede ser el sentido de las afirmaciones que a continuación esboza el mismo Tribunal:

«Esta condición de las libertades informativas requiere que, cada vez que con su ejercicio se contribuya con el debate sobre las cosas que interesan a todos, deban contar con un margen de optimización más intenso, aun cuando con ello se pudiera afectar otros derechos constitucionales». (Fund. Jur. $\left.\mathrm{N}^{\circ} 14\right)^{73}$

Y es que la referencia a que dichas libertades puedan ser objeto de limitaciones (y, por tanto, de ponderación), ${ }^{74}$ no es otra cosa que el reconocimiento de que esa posición privilegiada de la libertad de expresión e información se evalúa en cada caso. Es decir, su condición de libertad preferida no le viene dada por el hecho de tratarse de la libertad de expresión e información abstractamente considerada, sino porque su ejercicio contribuya con la formación de una opinión pública libre, sustento de la sociedad democrática.

\subsection{La mayor protección de los derechos fundamentales}

El principio de la mayor protección de los derechos fundamentales es una técnica americana que fue propugnada por ciertos Estados federales y,

72 STC recaída en el Exp. No 0905-2001-AA/TC, Fund. Jur. 13.

73 Aún así, véase lo formulado en la STC recaída en el Exp. N 1048-2001-AA/TC, Fund. Jur. $N^{\circ} 2$ : «Las libertades de información y expresión constituyen libertades preferidas en nuestro ordenamiento jurídico, pues su ejercicio es consustancial al régimen democrático".

74 Cf. Martín Borowski, «La restricción de los derechos fundamentales», en: Revista Española de Derecho Constitucional, N 59,2000 , p. 43 y ss. 
actualmente, se discute si podría o debería admitirse dentro del ordenamiento comunitario europeo.

Como se sabe, cuando se expidió la Constitución norteamericana en 1787, ésta no tenía una declaración de derechos (Bill of Rights), que solo se incorporó cuatro años más tarde, al introducirse las primeras diez enmiendas. Durante muchos años, la inserción de tales enmiendas en la Constitución federal se entendió en el sentido de que ningún estado parte de la unión "podía establecer en su ordenamiento un nivel de protección menor que el de la Declaración de Derechos federal». ${ }^{75}$

Sin embargo, en la década de 1970, a través de pronunciamientos de las cortes supremas de ciertos estados miembros de la Unión (en particular, por la más activista de todas ellas, el Tribunal Supremo de California) se planteó la posibilidad de entender a los derechos reconocidos en las constituciones estaduales con un mayor nivel de protección que aquel que dispensaba la Constitución Federal. Tal doctrina tuvo como caldo de cultivo, según recuerda Angel Rodríguez, la variación de la tendencia jurisprudencial que se avizoraba en torno a los derechos fundamentales, tras la sustitución de Earl Warren como Presidente de la Corte Suprema Federal, y el nombramiento de Warren Burger: «Bajo el nuevo ChiefJustice [...] comenzó un periodo de interpretación de la Constitución dominado por una aproximación stric-constructionist al texto constitucional, que implicaba construir restrictivamente, o al menos sin el carácter expansivo que habían tenido hasta entonces, los artículos de la Declaración de Derechos federal». ${ }^{76}$

El temor a un desmedido self restraint en la determinación del contenido constitucionalmente protegido de ciertos derechos fundamentales, como había sucedido en los primeros de vida republicana terminó con volver la atención sobre las constituciones estaduales y considerarlas como el campo apropiado para garantizar una mayor protección de derechos fundamentales. En la práctica, el principio permitió considerar que en la

75 Angel Rodríguez, "La mayor protección de los derechos fundamentales: dos ejemplos norteamericanos y algunas enseñanzas para el caso europeo", en: AA. VV., Estudios de Derecho Público. Homenaje a Juan José Ruíz-Rico, Editorial Tecnos, Madrid, 1997, T. 1, p. 367.

76Angel Rodríguez, «La mayor protección de los derechos fundamentales: dos ejemplos norteamericanos y algunas enseñanzas para el caso europeo", en: AA. VV., Estudios de Derecho Público. Homenaje a Juan José Ruíz-Rico, op. cit., p. 370. 
Constitución federal solo debía encontrarse el standard minimo protegido de los derechos fundamentales, debajo del cual no podría nunca situarse el derecho estatal. Y, contrario sensu, entender que las cláusulas de reconocimiento de derechos fundamentales de las constituciones estaduales podían ser interpretadas de modo que se dispensara una mayor protección de los mismos.

Una orientación similar, como se ha adelantado, se debate actualmente en Europa. ${ }^{7}$ Así, se ha sostenido, por ejemplo, que la Convención Europea de Derechos Humanos, de 1950, no puede considerarse como la que brinda una mayor protección de los derechos fundamentales, sino únicamente la que contiene un standard minimo, por debajo de la cual no pueden reconocerse derechos fundamentales en las constituciones nacionales, pero sí encontrarse la posibilidad de otorgarles un mayor nivel de protección. ${ }^{78}$

Aunque el Perú no sea un estado federal y tampoco participe de una unión de estados, en alguna que otra ocasión el Tribunal Constitucional ha implícitamente adoptado este criterio de interpretación de los derechos fundamentales. Así, por ejemplo, puede mencionarse la sentencia expedida en el caso Caja Rural de Ahorro y Créditos de San Martin (Exp. No 0905-2001-AA/TC), en la que sostuvo, implícitamente, que si bien el artículo $13^{\circ}$ de la Convención Americana de Derechos Humanos comprendía a la libertad de expresión dentro de la libertad de información, no podía arribarse a una conclusión semejante en sede interna, pues «aun cuando históricamente la libertad de información haya surgido en el seno de la libertad de expresión, y a veces sea difícil diferenciar la una de la otra, el referido inciso 4) del artículo $2^{\circ}$ de la Constitución las ha reconocido de manera independiente, esto es, como dos derechos distintos $y$, por tanto, cada uno con un objeto de protección distinto» (fund. Jur. $\mathrm{N}^{\circ} 9$ ).

De esta manera, el Tribunal Constitucional dejó una importante brecha para dispensar, en función del objeto protegido por cada uno de ellos,

77Cf. Reinhard Arnold, "La tutela dei diritti fondamentali nella Costituzione tedesca e l'influenza del diritto comunitario', en: Rivista Italiana di Diritto Pubblico Comunitario, $\mathrm{N}^{\circ} 4,1992$, p. 1158.

78 Antonio Ruggeri, "Carta Europea dei diritti e integrazione interordinamentale dal punto di vista della giustizia e della giurisprudenza costituzionale (Notazioni introduttive)", ponencia presentada a la "Giornata italo-spagnola su Carta Europea dei Diritti e riflessi sulla giustizia e la giurisprudenza costituzionale: Italia e Spagna a confrontom, en Taormina, el 4 de octubre de 2002. 
un nivel mayor de protección ambas libertades (v. gr. circunscribir el derecho de rectificación a la libertad de información y habilitar el derecho de réplica en torno a la libertad de expresión, que como el mismo Tribunal se encarga de precisar, garantiza la expresión de ideas, juicios de valor, sentimientos, que no pueden ser objeto de un test de veracidad).

Pero la utilización de este criterio de mayor protección de los derechos fundamentales también se ha utilizado en un sentido inverso. Es decir, considerando que las normas constitucionales, en ciertos casos, solo contienen un standard minimo de protección, que pueden ser ampliados en función de lo que se haya establecido en los tratados internacionales sobre derechos humanos en los que el Estado peruano sea parte y, en particular, en la Convención Americana. Ello ha sido posible tras considerarse que uno de los sentidos en los que cabe entender su IV Disposición Final y Transitoria es que en la Constitución solo se han enunciado los derechos constitucionales, de manera que la comprensión de su contenido, los alcances y límites a los cuales estén sujetos, el operador judicial debe encontrarlos en las disposiciones de los tratados sobre derechos humanos.

El Tribunal Constitucional ha destacado que la Cuarta Disposición Final y Transitoria de la Constitución, implica «una adhesión a la interpretación que, de los mismos (de los tratados sobre derechos humanos), hayan realizado los órganos supranacionales de protección de los atributos inherentes al ser humano y, en particular, el realizado por la Corte Interamericana de Derechos Humanos, guardián último de los derechos en la Región" (Exp. N²17-02-HC/TC).

En otro caso, al interpretar si el artículo $142^{\circ}$ de la Constitución prohibía el ejercicio del derecho de acceso a la justicia para impugnar las decisiones de no ratificación expedidas por el Consejo Nacional de la Magistratura [que una lectura literal de dicho precepto constitucional en efecto veda], el Tribunal invocaría el derecho a un recurso sencillo, rápido y efectivo reconocido en el artículo 25.1 de la Convención, para rechazar una interpretación semejante. ${ }^{79}$ Lo mismo ha hecho con el derecho al debido proceso, que la Constitución de 1993 parece haber circunscrito su ejercicio únicamente a sede judicial, y que el Tribunal, siguiendo a la Corte Interamericana de Derechos Humanos (Caso Tribunal Constitucional del Perú), ha sostenido que debe entenderse como que garantiza cuando un

79 Cfr. Sentencia recaída en el Exp. N²409-2002-AA/TC. 
individuo participa en cualquier clase de proceso o procedimiento ante órganos estatales, más allá del carácter jurisdiccional, administrativo o parlamentario que este pueda tener.

\subsection{La fuerza expansiva de los derechos fundamentales}

Como ya se dijo, los preceptos constitucionales que consagran derechos fundamentales son de gran abstracción y generalidad, lo que implica un amplio margen para la acción del intérprete. Este hecho, como pone de relieve Pérez Tremps, trae aparejado dos riesgos: en primer lugar, que al determinar el contenido protegido por cada uno de los derechos, el intérprete pretenda introducir en él todo tipo de pretensión, lo que desde luego no solo no es admisible, sino, incluso, puede generar que los derechos fundamentales se devalúen. En segundo lugar, puede suceder que el intérprete caiga en la tentación de ser él quien defina los contenidos de los derechos sin otro criterio que su propia discrecionalidad..$^{80}$

Evidentemente, ello no es así. Ni siquiera el legislador puede asignar libremente el contenido de los derechos fundamentales, incluso en aquellos casos en los que el derecho constitucional es de configuración legal; esto es, un derecho cuyo contenido la Constitución ha previsto que el legislador lo desarrolle (v. gr. el derecho a la protección adecuada contra el despido arbitrario del artículo $27^{\circ}$ de la Constitución peruana). ${ }^{81} \mathrm{El}$ intérprete de los derechos fundamentales, en efecto, no puede perder de vista que es en la Constitución -y en las fuentes a las que ella remitadonde, prima facie, tiene que hallarse el contenido constitucionalmente protegido de un derecho y, en general, el régimen jurídico al cual se encuentra sometido.

Precisamente, el principio de la fuerza expansiva de los derechos fundamentales constituye una importante herramienta en la comprensión de ese régimen jurídico, desde diversas perspectivas:

80 Cfr. Pablo Pérez Tremps, «La interpretación de los derechos fundamentales», en: Estudios de Derecho Constitucional. Homenaje al profesor doctor don Joaquín García Morillo, op. cit., pp. 123-124, a quien seguimos libremente en este apartado.

81 Así lo ha expresado el Tribunal Constitucional en su sentencia recaída en el Exp. $\mathrm{N}^{\circ}$ 976-2001-AA/TC, en la que destacó un contenido constitucional mínimo en los derechos de configuración legal, que el legislador debe respetar. 


\subsubsection{La titularidad de los derechos fundamentales}

Para empezar, el principio de la fuerza expansiva de los derechos fundamentales se proyecta en el ámbito de la titularidad de dichos derechos. En ese sentido, si los derechos fundamentales concretizan en cada momento histórico valores como la libertad, igualdad y dignidad, es dable entonces entender que, prima facie, es el ser humano el titular de los derechos que la Constitución reconoce. Y lo es desde el instante de la concepción, conforme expresa el inciso 1) del artículo $2^{\circ}$ de la Constitución.

Lo anterior no impide afirmar que la Constitución pueda establecer que determinadas personas, basándose en ciertos criterios, no puedan ser titulares de algunos derechos fundamentales. Es el caso, por ejemplo, de ciertos derechos políticos, cuya titularidad se encuentra, de diversas maneras, restringida a quienes no son nacionales. Lo mismo sucede con la posibilidad de titularizar el derecho de propiedad «dentro de cincuenta kilómetros de las fronteras", que le es negado a los extranjeros por el artículo $71^{\circ}$ de la Constitución.

Por otro lado, en la medida que los derechos fundamentales son derechos, prima facie, subjetivos, su titularidad no se extiende, por regla general (aunque no exenta de excepciones: v. gr. el derecho al debido proceso), a las personas jurídicas de derecho público y, respecto de las personas jurídicas de derecho privado, su titularidad alcanza a aquellos derechos que, como decía el artículo $3^{\circ}$ de la Constitución de 1979, le sean extendibles.

\subsubsection{Eficacia (vertical y horizontal) de los derechos fundamentales}

Asimismo, el principio de la fuerza expansiva de los derechos fundamentales predica que los derechos fundamentales no solo debe entenderse como "derechos públicos subjetivos", esto es, como derechos que solo se oponen al Estado y a sus poderes públicos, sino también como derechos subjetivos que se irradian en las relaciones entre particulares. ${ }^{82}$

Como se sabe, para el constitucionalismo decimonónico, la gran preocupación en torno a los derechos de la persona consistía en el riesgo de que ellos resultasen lesionados por el Estado. Ello se tradujo en hacer que

82 Cfr. Tomás de Domingo, «El problema de la Drittwirkung de los derechos fundamentales: una aproximación desde la filosofía del Derecho", en: Derechos y Libertades, $\mathrm{N}^{\circ}$ 11, Madrid, 2002, p. 251 y ss. 
los derechos fundamentales - particularmente los llamados derechos individuales - asegurasen un ámbito de autonomía individual, es decir, garanticen verdaderas zonas exentas de intervención estatal ilegítima. De ahí que, históricamente, se le haya asignado a la Constitución la función de regular las relaciones entre individuos y Estado, mientras que las relaciones entre simples particulares, en principio libres e iguales, se dejaba a merced del Código Civil, que de esta forma, como recordaría Konrad Hesse, ${ }^{83}$ se "convertía en el auténtico baluarte de la libertad» entre privados.

Los derechos fundamentales, así, terminaban por concebirse como derechos frente al Estado. Tal situación, evidentemente, tuvo que sufrir una mutación importante cuando dichos derechos fundamentales, además de derechos subjetivos, fueron también concebidos como el componente estructural básico del ordenamiento constitucional. Tal carácter de los derechos fundamentales terminó por convertirlos no solo en «verdaderos mandatos de actuación y deberes de protección especial de los poderes públicos", sino también como capaces de informar e irradiarse en «las relaciones entre particulares, actuando como verdaderos límites a la autonomía privada" ${ }^{84}$ extendiendo por tanto su eficacia a las relaciones entre privados. ${ }^{85}$ Tal eficacia inter privatos de los derechos es lo que el Tribunal Constitucional Federal Alemán ha denominado «fuerza de irradiación de los derechos fundamentales». ${ }^{86}$

En la sentencia recaída en el Exp. No 0976-2001-AA/TC, el Tribunal Constitucional peruano destacó que, en el ordenamiento nacional, los

83 Konrad Hesse, Derecho Constitucional y Derecho Privado, Editorial Civitas, Madrid, 1995, p. 37. Ver, asimismo, Cristian Starck, «Derechos fundamentales y derecho privado", en: Revista Española de Derecho Constitucional, $N^{\circ} 66,2002$, p. 65 y ss.

84 Así, la STC recaída en el Exp. N0976-2001-AA/TC, fund. Jur. $N^{\circ} 5$.

$85 \mathrm{Cfr}$. sobre el particular, Pedro de Vega, "La eficacia frente a particulares de los derechos fundamentales (La problemática de la Drittwirkung der Grundrechte)", en: AA. VV., Derechos fundamentales y Estado, Memoria del VII Congreso Iberoamericano de Derecho Constitucional, UNAM, México, 2002, p. 687 y ss. Del mismo modo, Víctor Ferreres Comella, "La eficacia de los derechos constitucionales frente a los particulares", en: AA.VV., Los derechos fundamentales, Editores del Puerto s.r.l., Buenos Aires, 2003, p. 41 yss.

86 Cfr. Erhard Denninger, «Principios constitucionales y derechos fundamentales como normas abiertas", en: Antonio López Pina, División de poderes e interpretación de la Constitución, op. cit., p. 183. 
derechos fundamentales no solo tienen una eficacia horizontal, ${ }^{87}$ sino también que esa eficacia es directa e indirecta, al mismo tiempo: «Los derechos fundamentales tienen eficacia directa en las relaciones inter privatos cuando esos derechos subjetivos vinculan y, por tanto, deben ser respetados, en cualesquiera de las relaciones que entre dos particulares se pueda presentar". Y es indirecta, pues al mismo tiempo ese horizontal effect de los derechos debe reflejarse en la ley y en la aplicación de la ley por los órdenes jurisdiccionales (Fun. Jur. $\mathrm{N}^{\circ} 6$ ) ${ }^{88}$

Tal cobertura de los derechos fundamentales a las relaciones entre particulares y especialmente el hecho de que tengan una eficacia directa, el Tribunal sustancialmente la deduce de la propia noción de Constitución. "Esta eficacia horizontal de los derechos fundamentales en las relaciones entre privados se deriva del concepto de Constitución como Ley Fundamental de la Sociedad» (Fun. Jur. $N^{\circ} 5$ ), como pone de relieve tanto el artículo $1^{\circ}$ como el artículo $38^{\circ}$ de la Constitución peruana. Pero también del hecho que los procesos constitucionales de la libertad que la Constitución ha establecido (habeas corpus, amparo y habeas data) no solo sirven para proteger la lesión de estos derechos cuando aquellas provienen del Estado, sino también cuando la lesión se origina por actos u omisiones de particulares. (STC Exp. No. 1124-2001-AA/TC y 09762001-AA/TC). ${ }^{89}$

87 Como señala Andrés Jana Linetzky [ «La eficacia horizontal de los derechos fundamentales", en: AA.VV., Los derechos fundamentales, op. cit., p. 53, nota 1], "la expresión vigencia horizontal se utiliza para graficar que los derechos fundamentales producen efectos entre privados, en oposición al efecto vertical en que solo resultan oponibles a las acciones de entes públicos».

88 Sobre la misma problemática en los Estados Unidos, Juan María Bilbao Ubillos, Los derechos fundamentales en la frontera entre lo público y lo privado (La noción de state action en la jurisprudencia norteamericana), McGraw-Hill, Madrid, 1997. Ver, asimismo, Mark Tushnet, "The issue of state action/horizontal effect in comparative constitutional Lawn, en: International Journal of Constitutional Law, Vol. 1, No 1, 2003, p. 79 y ss.

89 Sobre la problemática en torno a la eficacia horizontal de los derechos fundamentales y su protección, Cfr. Alexei Julio Estrada, «Los tribunales constitucionales y la eficacia entre particulares de los derechos fundamentales» en: Miguel Carbonell (Compilador), Teoría Constitucional y derechos fundamentales, México D.F., 2002, p. 203 y ss. 


\subsubsection{Limites de los derechos fundamentales}

Los derechos fundamentales, en cuanto elementos de un ordenamiento como lo es la Constitución, están sujetos a límites, ya sea para armonizar su ejercicio con otros derechos de su misma clase, ya sea con la finalidad de permitir la efectividad de otros bienes, principios o valores constitucionales. En el Estado Constitucional de Derecho, en efecto, la regla general es que los derechos son susceptibles de ser limitados, siendo la excepción que solo algunos de ellos puedan considerarse absolutos (v. gr. el derecho a no ser torturado). ${ }^{90}$

De ahí que, en primer lugar, el criterio de la fuerza expansiva de los derechos fundamentales imponga al intérprete, cada vez que se haya limitado un derecho, la tarea de verificar que esos límites se encuentren basados en la propia Constitución. No cabe una «desconstitucionalización» de la justificación jurídica de los límites a los derechos fundamentales. Lo que, como se ha advertido, no supone que los límites a un derecho solo puedan justificarse si la finalidad es armonizar su ejercicio con otro derecho del mismo rango. También es un criterio de justificación que los límites introducidos en la regulación jurídica de un derecho se sustenten en otros bienes constitucionalmente protegidos, como pueden ser el orden público constitucional, la seguridad jurídica, el interés nacional, entre otros. ${ }^{91}$

En segundo lugar, han de tratarse de límites legalmente estipulados, ya sea por efectos del principio de reserva de ley o, en su defecto, y con los mismos alcances, por la aplicación subsidiaria del principio de legalidad, expresado en el ordinal a) del inciso 24 del artículo $2^{\circ}$ de la Constitución de 1993. En efecto, no solo está prohibida la "desconstitucionalización" de la justificación" en la limitación de los derechos fundamentales, sino también la "deslegalización» del instrumento a través del cual se imponen esos límites. El primero alude a los criterios que pueden justificar la introducción de los límites; el segundo, en cambio, al medio (la fuente) a través del cual se deben fijar esas restricciones.

90 Cfr. entre nosotros, Samuel Abad Yupanqui, "Límites y respeto del contenido esencial de los derechos fundamentales», en: Themis, $N^{\circ} 21$, Lima, 1992, p. 7 y ss. Ver, asimismo, Juan José Solazábal, «Algunas cuestiones básicas de la Teoría de los Derechos Fundamentales", en: Revista de Estudios Políticos, N 71, 1991, p. 97 y ss.

91 Decididamente en contra, Christian Guzmán Napurí, «El principio de preferencia por los derechos fundamentales: un intento de fundamentación lógica”, en: Revista Jurídica del Perú, $N^{\circ} 27$, Lima, 2001, p. 1 y ss. 
Finalmente, como se deduce del inciso 9) del artículo $139^{\circ}$ de la Constitución, los límites constitucionalmente justificados y legalmente configurados han de interpretarse, en todo caso, de forma restrictiva precisamente por la fuerza expansiva ${ }^{92}$ de los derechos fundamentales. No cabe, pues, una interpretación extensiva de aquellas restricciones que se pudieran haber establecido al ejercicio de un derecho, por lo que se exige del intérprete una comprensión de esas restricciones en la forma que más se optimice su ejercicio.

\subsection{Respeto del contenido esencial de los derechos fundamentales}

El principio de la fuerza expansiva de los derechos fundamentales también despliega sus efectos en la determinación de los justos límites a los cuales se encuentra sometido, a su vez, la actividad limitadora de los derechos. En efecto, si la idea de armonizar y equilibrar el ejercicio de los derechos fundamentales con los demás derechos y bienes de su misma clase, tolera que se limiten los derechos, ello no debe entenderse en el sentido que el legislador se encuentre autorizado para suprimirlos o vaciarlos de contenido. ${ }^{93}$

La actividad misma de limitar un derecho, entonces, debe estar sujeta a un límite final, aquella frontera que permite evaluar si se trata de una tolerable restricción del derecho o, por el contrario, de una constitucionalmente inadmisible limitación. Esa zona de frontera es lo que las constituciones alemana y española han venido en denominar el «contenido esencial del derechom. ${ }^{94}$

92 Pablo Pérez Tremps, «La interpretación de los derechos fundamentales», en: Estudios de Derecho Constitucional. Homenaje al profesor doctor don Joaquín García Morillo, op. cit., p. 126.

93 Cfr. Luis Aguiar de Luque, "Los límites de los derechos fundamentales", en: Revista del Centro de Estudios Constitucionales, Nº 14, 1993, p. 25 y ss. Sobre el tema, Magdalena Lorenzo Rodríguez-Armas, Análisis del contenido esencial de los derechos fundamentales enunciados en el artículo 53.1 de la Constitución española, Editorial Comares, Granada, 1996.

94 Por cierto, la inexistencia de una cláusula semejante en la Constitución peruana, no quiere decir que el legislador nacional se encuentre habilitado para afectar el contenido esencial de los derechos fundamentales. Y es que, como señala Solazábal Echavarria, a disposiciones de esa naturaleza solo puede asignársele un carácter declarativo y no constitutivo, pues el carácter indisponible de dicho contenido esencial se deriva del hecho que 
Ciertamente, uno de los mayores problemas que hoy enfrenta la teoría de los derechos fundamentales es determinar qué es lo que se puede entender por "contenido esencial» de los derechos, más allá de considerarse, en términos generales, que ésta constituye la medida mínima, tendencialmente no sacrificable por algún otro derecho o bien constitucionalmente protegido. ${ }^{95} \mathrm{Y}$ aunque diversas sean las teorías que han pretendido dar cuenta de cómo determinar ese contenido esencial de los derechos, ${ }^{96} \mathrm{es}$ de advertir que más allá de la opción que en el plano teórico pueda asumirse, es común observarse en la jurisprudencia de los tribunales constitucionales un uso indistinto de las diversas teorías existentes, lo que se justifica en función de la estructura, la función y el significado que cada uno de los derechos fundamentales puedan tener. ${ }^{97}$

De ahí que si bien el pasarse una revista a estas diversas teorías sería más propio de una teoría jurídica en torno a los derechos fundamentales, no se puede perder de vista que, como ha puesto de relieve Tomás Requena López, ${ }^{98}$ su conocimiento constituye "un límite a la hermenéutica de las normas constitucionales" que reconocen derechos fundamentales.

mientras los derechos fundamentales son obra del poder constituyente, la limitación a los derechos es siempre obra de un poder constituido. Cfr. Juan José Solazábal Echavarría, "Algunas cuestiones básicas de la teoría de los derechos fundamentales", op. cit., pp. 102103.

95 Cfr. Luis Prieto Sanchís, "La limitación de los derechos fundamentales y la norma de clausura del sistema de libertades", en: Derechos fundamentales, neoconstitucionalismo y ponderación judicial, Editorial Palestra, Lima, 2002, p. 56 y ss.

96 En Italia, donde tampoco existe una cláusula semejante Alessandro Pace ( La garanzia dei diritti fondamentali nell'ordinamento costituzionale italiano: il ruolo del legislatore e dei giudici "comuni»» en: AA.VV., Nuove dimensioni nei diritti di liberta, Scritti in onore di Paolo Barile, Padova, 1999, p. 109 y ss.), ha señalado que "la ausencia de una disposición análoga no debe verse como una característica negativa del ordenamiento italiano, sino positiva. A su juicio, la ausencia de una disposición de esa clase significa que el legislador ordinario no está autorizado a distinguir aquello que es esencial de lo que no es esencial del contenido de un derecho constitucionalmente reconocido, lo que es muy importante sobre todo en los derechos cuyo contenido se identifica con el ejercicio mismo (agere licere), de tal manera que la disciplina del ejercicio redunda siempre sobre la disciplina del contenido, y los límites al ejercicio se resuelven en limites al contenido".

97 Cfr. Antonio Luis Martínez-Pujalte, La garantía del contenido esencial de los derechos fundamentales, CEC, Madrid, 1997, p. 27 y ss.

98 Tomás Requena López, Sobre la función, los medios y los límites de la interpretación de la Constitución, Editorial Comares, Granada, 2001, p. 117 y ss. 


\section{a) La teoría absoluta del contenido esencial}

Los partidarios de la teoría absoluta individualizan dos contenidos en cada derecho fundamental: uno accesorio, sobre el que el legislador puede llevar adelante su tarea limitativa, y un contenido esencial, cuya afectación invalidaría la actividad limitadora.

Desde este punto de vista, ambos contenidos (el esencial y el accesorio) se presentarían como elementos identificables y permanentes en todo derecho fundamental. ${ }^{99}$ Pero solo el primero - el denominado contenido esencial - tendría la condición de elemento indisponible para el legislador. ${ }^{100}$ Como ha expresado Luciano Parejo Alfonso, «contenido esencial no puede ser equivalente a mero contenido de los derechos subjetivos públicos. La diferencia entre ambos radica precisamente en la «esencialidad": solo aquella parte de los elementos integrantes del contenido que sean absolutamente indispensables para la recognoscibilidad jurídica del derecho en cuanto tal [...] puede considerarse constitutiva del contenido esencial». ${ }^{101}$

Se debate sobre qué es lo que debe entenderse por contenido esencial. Según Herbert Kruger, ese contenido esencial coincide con el fin que persigue garantizar el derecho fundamental. Para Schneider, en cambio, el núcleo duro de cada derecho se homologa con el contenido mínimo de libre autodeterminación de la persona garantizado por cualquier derecho fundamental y sobre el cual debería estar excluida cualquier acción esta-

99 En el sentido de no diferenciar un «contenido esencial» de otros contenidos, entre nosotros, Luis Castillo Córdova, "Acerca de la garantía del contenido esencial y de la doble dimensión de los derechos fundamentales", en: Revista de Derecho, N³, Universidad de Piura, Piura 2002, p. 25 y ss. En sentido inverso, esto es, de no confundir el contenido esencial, como límite indisponible al legislador, del contenido protegido por todo derecho, que incluye el contenido esencial y además el efectivo goce del derecho en el marco de su regulación legal, Ana Aba Catoira, La limitación de los derechos en la jurisprudencia del Tribunal Constitucional español, Tïrant lo Blanch, Valencia, 1999, p. 203.

100 Cfr. una sintética exposición, en: Antonio-Luis Martínez-Pujalte, La garantía del contenido esencial de los derechos fundamentales, CEC, Madrid, 1997, pp. 22-23.

101 Luciano Parejo Alfonso, «El contenido esencial de los derechos fundamentales en la jurisprudencia constitucional: a propósito de la Sentencia del Tribunal Constitucional del 8 de abril de 1981 ", en: Revista Española de Derecho Constitucional, N³, 1981, p. 187. 
tal. ${ }^{102}$ En cierta forma, esta concepción del contenido esencial de los derechos fundamentales fue expresada por el Tribunal Constitucional español en su conocida sentencia 11/1981: "Constituyen el contenido esencial de un derecho subjetivo - diría el Tribunal español-aquellas facultades o posibilidades de actuación necesarias para que el derecho sea reconocible como pertinente al tipo descrito y sin las cuales deja de pertenecer a ese tipo y tiene que pasar a quedar comprendido en otro, desnaturalizándose por decirlo así. [...] Se puede [...] hablar de una esencialidad del contenido del derecho para hacer referencia a aquella parte del contenido del derecho que es absolutamente necesaria para que los intereses jurídicamente protegibles, que dan vida al derecho, resulten real, concreta y efectivamente protegidos. De este modo se rebasa o se desconoce el contenido esencial cuando el derecho queda sometido a limitaciones que lo hacen impracticable, lo dificultan más allá de lo razonable o lo despojan de la necesaria protección»». ${ }^{103}$

Desde este punto de vista, además de exigirse que toda actividad limitadora del derecho fundamental se encuentre suficientemente justificada, se exige, además, que ésta respete el contenido esencial del derecho. Lo que significa que no basta evaluar si la limitación efectuada a un derecho fundamental se justifica constitucionalmente, pues pudiendo contar «a su favor con buenas razones, resultará ilegítima si llega a dañar el contenido esencial de un derechom. ${ }^{104}$

Por otro lado, que el contenido esencial del derecho se presente como indisponible para el legislador, no quiere decir que cualquier limitación sobre el contenido accesorio pueda ser tolerable. Ellas no han de ser arbitrarias, pues también se encuentran sujetas a una justificación constitucionalmente admisible.

102 Citados por Ilenia Massa Pinto, "La discrezionalitá politica del legislatore tra tutela costituzionale del contenuto essenziale e tutela ordinaria caso per caso dei diritti nella piu recente giurisprudenza della Corte Costituzionale», en: Giurisprudenza Costituzionale, $\mathrm{N}^{\circ}$ 2, 1998, pp. 1313-1314.

103 Citado por Samuel Abad Yupanqui, «Límites y respeto del contenido esencial de los derechos fundamentales", en: Themis, $\mathrm{N}^{\circ} 21,1992$, p. 10. Una visión general de lo que sucede con los diversos derechos fundamentales, en: Juan Andrés Muñoz Arnau, Los límites de los derechos fundamentales en el Derecho Constitucional español, Editorial Aranzadi, Pamplona, 1998.

104 Luis Prieto Sanchíz, Estudios sobre derechos fundamentales, op. cit., p. 148. 
Ciertamente esta teoría absoluta del contenido esencial permite explicar lo que normalmente sucede con aquellos derechos fundamentales que cuentan con una estructura simple de aquello que garantizan. Piénsese, por ejemplo, en el ne bis in idem, ya sea en su vertiente sustancial o procesal; esto es, como prohibición de una doble sanción o como prohibición de un doble juzgamiento por un mismo hecho. Pero rara vez permite dar respuesta a derechos que tienen un contenido protegido más complejo, como puede ser el derecho a un proceso que dure un plazo razonable, cuyo contenido esencial, desde luego, no se identifica con el plazo legalmente establecido. ${ }^{105}$

Asimismo, se cuestiona a la teoría absoluta del contenido esencial de partir de un dato que en la práctica puede generar más problemas que los que busca solucionar. $Y$ es que cabe interrogarse, en efecto, si en todo derecho fundamental es posible destacarse con nitidez tanto el contenido accesorio como su núcleo duro. Si las cláusulas que reconocen derechos fundamentales son abiertas y valorativas, ¿cómo identificar ambos contenidos en cada uno de los derechos fundamentales?. Como expresa Martínez Pujalde, una semejante división en cada uno de los derechos fundamentales abre la posibilidad de que el legislador - quien es el constitucionalmente encargado de precisar los alcances y los límites de los derechos fundamentales - establezca discrecionalmente cuál es ese contenido accesorio y cuál el contenido esencial de cada uno de los derechos, ${ }^{106}$ lo cual no deja de prestarse a arbitrariedades.

Finalmente, se cuestiona a la teoría absoluta del contenido esencial obligar a efectuar una distinción entre dos compartimentos estancos del derecho (su contenido esencial y el accesorio) que no deja de ser completamente artificial.

\section{b) La teoria relativa del contenido esencial}

La teoría relativa no parte de considerar que en el contenido protegido por cada derecho fundamental exista uno que sea accesorio y otro que sea

105 Permítaseme la remisión a un trabajo previo: Edgar Carpio Marcos, «El derecho a un proceso que dure un plazo razonable en el Anteproyecto de Reforma Constitucional», en: Revista Peruana de Derecho Público, N³, Lima, 2001, p. 37 y ss. Asimismo, Daniel Pastor, El plazo razonable en el proceso penal del Estado de Derecho, Editorial Ad Hoc, Buenos Aires, 2002.

106 Antonio-Luis Martínez-Pujalte, La garantía del contenido esencial de los derechos fundamentales, op. cit., pp. 22-23. 
esencial, y que se afecta este último, cuando se pasa la frontera del contenido accesorio. Por el contrario, considera que tal afectación se produce siempre que la limitación se presente como injustificable.

Desde esta perspectiva, el contenido esencial de un derecho se determina en el razonable equilibrio que resulta de la ponderación entre el valor comprometido en el derecho en cuestión y aquel que se encuentra en los otros derechos o bienes constitucionales con los que colisiona. "El contenido esencial, según tal teoría, finalizaría por hacer coincidir con el llamado límites de los límites, la mera exigencia de justificar cualquier intervención limitativa en el ejercicio de los derechos fundamentales». ${ }^{107}$ Como no duda en afirmar Robert Alexy, para la teoría relativa "el contenido esencial es aquello que queda después de una ponderación. Las restricciones que responden al principio de proporcionalidad no lesionan la garantía del contenido esencial aun cuando en el caso particular no dejen nada del derecho fundamental». ${ }^{108}$

De ahí que, a diferencia de lo que sucede con la teoría absoluta, el contenido esencial de un derecho no aparezca determinado positivamente, esto es, precisándose en qué es lo que constituye aquel mínimo irreductible del derecho y que no puede ser afectado; sino, al contrario, determinado en sentido negativo, es decir, calificándose como inconstitucional una determina limitación al derecho por no haber satisfecho el test de proporcionalidad. ${ }^{109}$

Desde luego, esta teoría tampoco ha estado ajena a críticas. Una de las más serias es aquella que ha destacado que la garantía del respeto del contenido esencial de los derechos, bajo sus postulados, queda reducida a una mera garantía formal y retórica, un «instrumento sumamente peligroso para trabar una interpretación magis ut valeat de la disciplina constitucional en

107 Ilenia Massa Pinto, "La discrezionalitá politica del legislatore tra tutela costituzionale del contenuto essenziale e tutela ordinaria caso per caso dei diritti nella piú recente giurisprudenza della Corte Costituzionale», en: Giusrisprudenza Costituzionale, № 2, 1998, p. 1314.

108 Robert Alexy, Teoría general de los derechos fundamentales, CEC, Madrid, 1997, p. 288.

109 Cfr. Carlos Bernal Pulido, El principio de proporcionalidad y los derechos fundamentales, CEPC, Madrid, 2003, p. 533 y ss. Asimismo, Omar Chessa, «Brevi note sul "contenuto essenziale" (dei diritti inviolabili) come parametro del giudizio di costituzionalitá", en: AA. VV., Il parametro nel giudizio di costituzionalitá, Giappichelli editore, Torino, 2000 , p. 285. 
materia de derechos fundamentales". ${ }^{110} \mathrm{Y}$ es que si de lo que se trata es simplemente de justificar la constitucionalidad de los límites, entonces, en esa evaluación no asume papel alguno el derecho fundamental, que termina de esa forma relativizándose, al extremo de poder ser sacrificado. ${ }^{111}$

\section{c) La teoria institucional del contenido esencial}

Una teoría intermedia, que busca «demostrar que no raras veces las "teorías", que se contraponen de manera inconciliable desarrollan puntos de vista que no se excluyen absolutamente y que, por el contrario, pueden ser a menudo reconducidas a una conciliación non modo sed etiam", es la que postula Peter Häberle. ${ }^{112}$

Según Häberle, dado que en la Constitución coexisten derechos y bienes, los límites de los derechos no pueden entenderse como elementos ajenos a esos derechos. El contenido esencial de un derecho, en efecto, no puede «ser desprendido «de por sí» e independientemente del conjunto de la Constitución».. ${ }^{113}$ Ambos constituyen, a su juicio, una unidad, de manera que la determinación del contenido esencial de los derechos fundamentales y la validez de sus límites «se determinan recíprocamente». ${ }^{114}$ "En el contenido esencial está comprendida también la tutela de los bienes que poseen rango igual o superior. Hablando con metáforas: en el contenido esencial de los derechos fundamentales se refleja la totalidad del sistema constitucional de valores. Tal concepción consiente en reconocer que la necesaria ponderación entre los intereses, en caso de obtenerse por medio del equilibrio, no ocurre atribuyendo al menos una precedencia a bienes jurídicos heterogéneos respecto al derecho fundamental, sino que ocurre porque los bienes reconocidos merecedores de tutela se encuentran en el contenido esencial de los derechos fundamentales mismos».. ${ }^{115}$

110 Ilenia Massa Pinto, "La discrezionalitá politica del legislatore tra tutela costituzionale del contenuto essenziale e tutela ordinaria caso per caso dei diritti nella piú recente giurisprudenza della Corte Costituzionalen, en: Giusrisprudenza Costituzionale, op. cit., p. 1312.

111 La absolución a las críticas formuladas a la ponderación como técnica que termina sacrificando los derechos fundamentales por razón de fines colectivos, las ha formulado Robert Alexy en un reciente trabajo: "Epílogo a la Teoría de los derechos fundamentales" en: Revista Española de Derecho Constitucional, No 66, 2002, p. 13 y ss.

112 Peter Häberle, La libertad fundamental en el Estado Constitucional, Fondo Editorial PUCP, Lima, 1997, pp. 126-127.

113 Peter Häberle, op. cit., p. 117.

114 Peter Häberle, op. cit., p. 121.

115 Peter Häberle, La libertad fundamental en el Estado Constitucional, op. cit., p. 121. 
Pero así como en la ponderación con otros bienes no puede verse una relativización de los derechos fundamentales, tampoco se puede olvidar que el contenido esencial de un derecho "es algo sustancial». ${ }^{116}$ En efecto, "el contenido esencial no pierde la «sustancialidad», si es determinado con referencia a otros bienes jurídicos poseedores de rango igual o superior, porque estos bienes jurídicos también poseen una sustancia que debe ser determinada». De ahí que "la interacción entre cada uno de los bienes constitucionales no los priva de sustancia; al contrario, más bien conduce a ésta». ${ }^{117}$

De esta manera, se rescata lo fundamental de la teoría absoluta del contenido esencial, esto es, evitar una relativización de los derechos fundamentales mediante la identificación de un núcleo duro, «un campo en el cual, sin sombra de duda, no existen más bienes de rango igual o superior que puedan delimitar legítimamente estos derechos fundamentales». ${ }^{118}$ $\mathrm{Y}$, al mismo tiempo, esa tutela sobre el contenido esencial es la consecuencia - como predica la teoría relativa - de un equilibrio de bienes constitucionales, que no se presentan como "externos" al contenido del derecho, sino como elementos «internos». De manera que ni hay una relativización de los derechos fundamentales, ni tampoco la posibilidad de un sacrificio de éstos. ${ }^{119}$

d) El doble carácter de los derechos fundamentales y las teorias subjetiva $y$ objetiva del contenido esencial

Paralelamente al debate entre la teoría relativa y absoluta del contenido esencial, a partir del doble carácter de los derechos fundamentales, en la doctrina alemana se ha planteado el debate sobre si la garantía del contenido esencial recae sobre los derechos fundamentales - en cuanto derechos subjetivos-o, a su turno, en cuanto institutos recogidos en normas positivas.

Como antes se ha expuesto, los derechos fundamentales, en el Estado constitucional, tienen un doble carácter. En palabras del Tribunal Constitucional peruano, citando a su homólogo español, los derechos funda-

$116 \mathrm{Ibid}$, p. 123.

117 Ibid, pp. 123-124.

118 Ibid, p. 124.

119 Una exposición sintética del pensamiento de Häberle, en: Magdalena Lorenzo Rodríguez-Armas, Análisis del contenido esencial de los derechos fundamentales enunciados en el artículo 53.1 de la Constitución española, op. cit., p. 137 y ss. 
mentales no solo constituyen derechos subjetivos reconocidos a los individuos (carácter subjetivo), sino también el «establecimiento de verdaderos valores supremos, es decir, el componente estructural básico del orden constitucional, en razón de que son la expresión jurídica de un sistema de valores, que, por decisión del constituyente, ha de informar el conjunto de la organización jurídica y política [...] el fundamento del orden jurídico y de la paz social" [carácter objetivo (Fun. Jur. N. 5, STC Exp. $\mathrm{N}^{\circ}$ 0976-2001-AA/TC)].

Desde esta perspectiva, para cierto sector de la doctrina alemana la garantía del contenido esencial tendría por objeto proteger a los derechos fundamentales en cuanto reconocedores de un haz de potestades a favor de los individuos, de manera que cualquier limitación que los impida, terminaría afectando ese contenido esencial (Teoría subjetiva). Según Stein, ${ }^{120}$ "los derechos fundamentales resuelven el conflicto entre los intereses particulares y los intereses estatales, esencialmente en contra de los intereses estatales. La primacía de los intereses protegidos por los derechos fundamentales no significa una total postergación del Estado, sino su sometimiento a la misión de proteger los intereses de los particulares». ${ }^{121}$ De ahí que "si la limitación llega tan lejos que los particulares no pueden de ninguna manera disfrutar de los intereses protegidos por el derecho fundamental, debido a que se cierran las posibilidades de su ejercicio, se considera que tal limitación afecta a su contenido esencial y, por lo tanto, que es inconstitucional". ${ }^{122}$

Para la teoría objetiva, en cambio, la garantía del contenido esencial no tendría por objeto proteger el derecho subjetivo, sino «la garantía constitucional de esferas de vida reguladas y organizadas según principios de libertad". ${ }^{123}$ Son los institutos que se encuentran en las normas jurídicas constitucionales, de donde se derivan los derechos, lo que realmente se

120 Su pensamiento se haya sintetizado en Juan Carlos Gavara de Cara, Derechos fundamentales y desarrollo legislativo. La garantía del contenido esencial de los derechos fundamentales en la Ley Fundamental de Bonn, CEC, Madrid, 1994, p. 27.

121 Cfr. Klaus Stern, "Riflessioni sull' interpretazione dei dirittifondamentali», op. cit., p. 236.

122 Juan Carlos Gavara de Cara, Derechos fundamentales y desarrollo legislativo. La garantía del contenido esencial de los derechos fundamentales en la Ley Fundamental de Bonn, op. cit., p. 28.

123 Peter Häberle, La libertad fundamental en el Estado Constitucional, op. cit., p. 163. 
persigue proteger, de manera que sería constitucional que en un caso concreto se afecte el derecho subjetivo de un individuo, si es que tras de ello se busca preservar a los derechos fundamentales entendidos como instituciones. Según Peter Lerche, "como contenido esencial protegido absolutamente debe entenderse el contenido institucional garantizado en el correspondiente derecho fundamental». ${ }^{124}$ De esta manera, para la teoría objetiva, lo protegido por el contenido esencial no es el sacrificio de determinadas posiciones individuales, sino los derechos fundamentales en sus alcances generales.

Según Häberle, el aspecto institucional de los derechos fundamentales está estrictamente ligado al de los derechos fundamentales como derechos subjetivos. Así, los ordenamientos objetivos que Häberle encuentra garantizados también por los derechos fundamentales, adquieren un carácter de libertad por el hecho de que el ordenamiento jurídico asocia a esos derechos subjetivos, ligándolos al libre desarrollo de la personalidad. De manera que si los derechos fundamentales contienen garantías de derecho objetivo o de tipo institucional, éstos no pueden eliminar el contenido del derecho subjetivo.

Como en el caso de las teorías relativa y absoluta, también las teorías subjetiva y objetiva han sido recepcionadas en la jurisprudencia del Tribunal Constitucional Federal Alemán. No obstante, en la famosa sentencia sobre la "cogestión» (Mitbestimmung), el Tribunal se ha inclinado por la teoría subjetiva, recordando que en base a su historia y a su significado actual, los derechos fundamentales son, en primer lugar, derechos individuales, derechos del hombre y del ciudadano, que tienen por objeto la protección de ámbitos particularmente reservados. La función de los derechos fundamentales como principios objetivos refuerza su carácter vinculante, pero tiene, sin embargo, su propia raíz en ese significado primario. Esta función no es separable de su auténtico núcleo y no puede ser considerado autónomo en su estructura de norma de derecho objetivo, en la cual el significado originario y perenne de los derechos fundamentales perdería su significado. ${ }^{125}$

124 Juan Carlos Gavara de Cara, Derechos fundamentales y desarrollo legislativo. La garantía del contenido esencial de los derechos fundamentales en la Ley Fundamental de Bonn, op. cit., pp. 37-38.

125 Es la síntesis de Christian Starck ["Il diritti fondamentali nel Grundgesetz della Repubblica Federale di Germaniar, op. cit., p. 2534] sobre la referida sentencia. 
Cabe advertir, finalmente, que ambas teorías, en cierta forma se hallan relacionadas con la teoría relativa y objetiva del contenido esencial. Así, por ejemplo, la teoría subjetiva, en la medida que buscan preservar un "núcleo esencial radicalmente invulnerable de los derechos fundamentales», ${ }^{126}$ tiene cierto parentesco con la teoría absoluta del contenido esencial. En cambio, la teoría objetiva "guardaría a su vez conexión con las tesis relativas, que tratan de dilucidar ante todo el problema de la justificación de las restricciones, y se preocupan preferentemente por la preservación en abstracto de los derechos fundamentales». ${ }^{127}$

\subsection{La ponderación (balancing) de los derechos fundamentales}

Uno de los métodos habitualmente utilizados en la solución de conflictos que atañen a derechos fundamentales es lo que se denomina «ponderación" o "balancing".

Se discute si el balancing es un criterio interpretativo o solo una técnica de argumentación ${ }^{128}$ para resolver conflictos entre derechos fundamentales y bienes constitucionalmente protegidos, una vez que se ha efectuado su interpretación. ${ }^{129}$ Se tratan, por cierto, de dos actividades que, en el plano abstracto, pueden ser distinguidas, pero que, en la práctica, se encuentran muy compenetradas, al punto que se ha señalado que es evanescente e incierta cualquier línea de demarcación que se pudiera practicar. $^{130}$

126 Antonio Luis Martínez-Pujalte, La garantía del contenido esencial de los derechos fundamentales, op. cit., p. 34 .

127 Antonio Luis Martínez-Pujalte, La garantía del contenido esencial de los derechos fundamentales, op. cit., p. 35 .

128 Sobre el tema, Alberto Vespaziani, Interpretazioni del bilanciamento dei diritti fondamentali, op. cit., p. 100 y ss. Giorgio Pino ["Teoria e pratica del bilanciamento: tra libertá di manifestazione del pensiero e tutela dell'identitá personales" en: Danno e Responsabilitá, $N^{\circ} 6,2003$, p. 577] considera que es una técnica de argumentación.

129 Para Riccardo Guastini [ ¿L'interpretazione della Costituzione. III Le tecniche», en: Lezioni di Teoria Costituzionale, Giappichelli Editore, Torino, 2001, p. 166], "La ponderación no es para nada una técnica de interpretación... Un juicio de valor es cualquier cosa que una tesis interpretativa».

130 Antonio Ruggeri, "Ragionevolezza e valori, attraverso il prisma della giustizia costituzionalè en: Diritto e Societá, N 4, 2000, pp. 600-601, donde, además, se evalúa el tema y se afirma que, al final, el balancing no es sino la prolongación de la interpretación y viceversa. 
Según Roberto Bin, por ejemplo, «si la interpretación mira a asignar un significado al discurso del legislador (a la disposición), el balanceamiento de los intereses [...] (busca) brindar una solución satisfactoria en presencia de un conflicto entre intereses. Una solución que no pretende colocarse como único significado normativo recabable del texto legislativo [...] sino que pertenece al mundo de las decisiones y de sus relativas justificaciones retóricas. El balanceamiento no pretende fijar el único significado atribuible a una disposición, sino individualizar el punto de equilibrio entre las posiciones de intereses en juego en el caso específico, lo que presupone, desde luego, una precedente actividad interpretativa de reconstrucción y calificación de los intereses por conciliar)». ${ }^{131}$

Como se puede apreciar, no bien se observa las relaciones entre interpretación y balancing, inmediatamente se observa que el uno presupone al otro, y viceversa. La interpretación, en efecto, recae sobra una disposición constitucional. La ponderación (actividad), en cambio, sobre intereses o bienes que esas disposiciones contienen. En un caso de colisión entre derechos fundamentales, habitualmente se parte por identificar los bienes o intereses en conflicto (balancing actividad), se realiza la interpretación de las disposiciones que los reconocen (interpretación), se advierte las circunstancias del caso y, luego, se procede a realizar el balanceamiento de los intereses a fin de brindar una solución al caso (balancing producto). ${ }^{132}$

La ponderación presupone un conflicto o una colisión entre derechos fundamentales. Este tipo de conflictos, y la necesidad de resolverlos mediante la ponderación, constituye la forma normal de resolver este tipo de problemas en las constituciones modernas, que se deriva del hecho que el reconocimiento de los derechos se realiza en una tabla, en la que no solo coexisten con "otros" derechos del mismo peso, sino, además, con otros bienes, individuales o colectivos de idéntico rango. Desde esta perspectiva, como afirma Alexy, el concepto de "colisión entre derechos fundamentales» puede entenderse con un doble alcance: en sentido estricto,

131 Roberto Bin, Diritti e argomenti. Il bilanciamento degli interessi nella giurisprudenza costituzionale, Giuffré editore, Milano, 1992, p. 60.

132 Según Gino Scaccia ["Il bilanciamento degli interessi come tecnica di controllo costituzionale", en: Giurisprudenza Costituzionale, Fasc. 6, 1998, pp. 3966-3967], la primera manifestación del balancing es, en rigor, una actividad interpretativa y no una ponderación. Idem, Gli strumenti della ragionevolezza nel giudizio costituzionale, op. cit., p. 309 y ss. 
cuando la colisión se produce exclusivamente entre derechos fundamentales. En sentido amplio, en cambio, cuando tal colisión se produce con otros bienes o valores del mismo rango. ${ }^{133}$

En cualquier caso, un presupuesto inexorable de la técnica de la ponderación es que el conflicto se presente entre bienes y/o derechos que tienen en el ordenamiento jurídico el mismo rango. En tales casos, como afirman, entre otros Giorgio Pino o Riccardo Guastini, ${ }^{134}$ el juez constitucional se encuentra ante una particular hipótesis de antinomia, pues, dado el mismo rango constitucional de los bienes y derechos en conflicto, no cabe que se apele a los criterios de lex superior derogat lex inferiori, al criterio lex posteriori derogat lex priori ni tampoco al de lex specialis derogat lex generali. No es aplicable el primer criterio, pues se tratan de derechos que tienen el mismo rango normativo. Tampoco el segundo, pues se trata de derechos y bienes reconocidos coetáneamente en un mismo documento normativo. Y tampoco el último, dado que «entre las normas que fundan los dos derechos en conflicto no se presenta una relación de especialidad; ninguna de las dos normas es especial respecto de la otran: ${ }^{135}$ ambos son mandatos de optimización.

En la medida que cada derecho o bien constitucionalmente protegido tiene una finalidad y, por tanto, mandatos de optimización particularizados, el conflicto no puede resolverse, en términos generales, mediante la técnica de la subsunción. Esta última presupone la colisión de dos «reglas", cuya aplicación requiere que se presenten los supuestos de hecho o derecho que contemplan. Las reglas son normas con estructura condicional, esto es, son aplicables o no son aplicables. La subsunción, como técnica para resolver conflictos, presupone que el caso «entre» en lo dispuesto por el supuesto previsto en la regla. Definitivamente aquello no sucede en la colisión entre derechos fundamentales. Estos no son normas que tengan un supuesto predeterminado, al cual adscriban una conse-

133 Robert Alexy, "Collisione e bilanciamento quale problema di base della dogmatica dei diriti fondamentalin, en: Massimo La Torre e Antonino Spadaro, La ragionevolezza nel diritto, Giappichelli editore, Torino, 2001, pp. 28-29.

134 Giorgio Pino, "Teoria e pratica del bilanciamento: tra libertá di manifestazione del pensiero e tutela dell'identitá personales", en: Danno e Responsabilitá, N 6, 2003, p. 580. Riccardo Guastini, "L'interpretazione della Costituzione. III Le tecniche» en: Lezioni di Teoria Costituzionale, Giappichelli Editore, Torino, 2001, p. 164.

135 Giorgio Pino, "Teoria e pratica del bilanciamento: tra libertá di manifestazione del pensiero e tutela dell'identitá personales, en: Danno e Responsabilitá, op. cit., p. 580. 
cuencia jurídica, sino mandatos de optimización que exigen ser aplicados y actualizados de modo gradual. Por tanto, las exigencias de aplicación de uno no excluye la del otro.

Como nuevamente afirma Alexy, las colisiones entre derechos fundamentales se definen como colisión de principios. Y el procedimiento que sirve para solucionar la colisión de principios no es otro que la ponderación. "Principios y ponderación son dos aspectos de la misma cosa. El primero es de carácter teórico normativo, el otro de carácter metodológicon. ${ }^{136}$

Pero si la técnica de la ponderación permite resolver conflictos entre dos principios, cabe preguntarse si la ponderación, en sí misma, es un principio, o acaso solo una regla para solucionar conflictos entre aquellos. Según Jorg Luther, ${ }^{137}$ en afirmación que se extiende a la actividad de cualquier Tribunal Constitucional, éstos no someten la ponderación a un "contrabalanciamiento" con otros principios. Es decir, no consideran al balancing como un principio, sino, fundamentalmente como una «regla», con características de uso jurisdiccional para la solución de conflicto entre principios.

Cabe advertir, asimismo, que aún cuando el balancing sea hoy una técnica a la que frecuentemente apelan los tribunales constitucionales, no todos ellos lo hacen del mismo modo. Depende de la naturaleza de la controversia constitucional que se les someta y también del proceso en el cual se presenta dicha controversia. Ello es particularmente relevante en casos como el peruano, en el que el Tribunal Constitucional no solo actúa como órgano de control constitucional de las leyes, esto es, tiene como tarea la de juzgar en abstracto si una ley viola o no un derecho fundamental, sino al que también se le ha confiado la de resolver casos concretos sobre violaciones de derechos. ${ }^{138}$

136 Robert Alexy, «Collisione e bilanciamento quale problema di base della dogmatica dei diriti fondamentalin, en: Massimo La Torre e Antonino Spadaro, La ragionevolezza nel diritto, op. cit., p. 37.

137 Jorg Luther, "Ragionevolezza (delle leggi)", en: Digesto Pubblico, Vol. XII, 1991, p. 348.

138 Este es un rasgo que, por lo demás, es común a los tribunales constitucionales de esta parte del Continente. Sobre el particular, véase el trabajo de Humberto Nogueira Alcalá, "Las competencias de los tribunales constitucionales de América del Sur", en: Ius et Praxis, Año 8, N $^{\circ}$ 2, Talca, 2002, p. 71 y ss. 
De ahí que quepa distinguirse, para utilizar terminología usada en el derecho estadounidense, entre el definitional balancing y el ad hoc balancing.

a) definitional (o categorial) balancing

En el primero, el conflicto entre derechos fundamentales, o entre un derecho y un principio constitucional, se resuelve individualizando una regla general y abstracta, susceptible de aplicarse para casos futuros. "Es un procedimiento que tiende a individualizar, sobre la base del fin, de la ratio de la disposición constitucional en cuestión, una línea de demarcación entre aquello que entra "en la» y aquello que "está fuera» de la garantía constitucional, destacando por tanto una regla jurídica, general y abstracta, si bien provisoria, modificable y susceptible de entrar en crisis en casos límite (como es lo habitual en algunos precedentes judiciales)m. ${ }^{139}$

Así, por ejemplo, se fija un criterio de aplicación general cuando el Tribunal Constitucional identifica en términos abstractos todas aquellas actividades que entran en la esfera protegida de un derecho o cuando las excluye. Así, por ejemplo, cuando el Tribunal excluyó del contenido protegido del derecho al juez natural la posibilidad de que civiles puedan ser procesados (aún por los delitos de traición a la patria y terrorismo) por tribunales militares [STC Exp. $\left.\mathrm{N}^{\circ} 010-2002-\mathrm{AI} / \mathrm{TC}\right] .{ }^{140}$ En tales casos, como explica Gino Scaccia, ${ }^{141}$ se tiende «a consolidar, para cualquier materia, una determinada garantía de intereses, que se coloca como límite y directiva para el legislador, pero, al mismo tiempo, también constituye un criterio orientador del control de legitimidad constitucional». En lo sucesivo, en efecto, el legislador deberá tener en cuenta que el derecho al juez natural no tolera que se habilite con competencia a los tribunales militares para juzgar civiles.

139 Roberto Bin, Diritti e argomenti. Il bilanciamento degli interessi nella giurisprudenza costituzionale, op. cit., p. 65, nota $\mathrm{N}^{\circ} 160$.

140 Aunque aparentemente planteado en un esquema de orden jerarquizado de derechos fundamentales (derecho de defensa c/ cosa juzgada, con referencia al primero de ellos como de un "mayor valor material»), ex categorial balancing el Tribunal Constitucional ha señalado, como criterio general, que no hay cosa juzgada —o que esta es relativa, aún si proviene de una sentencia de amparo- si ésta se obtiene con violación del derecho de defensa». Cfr. STC recaída en el Exp. N0612-1998-AA/TC, Fun. Jur. Nº 7. 
«El definitional approach tiende a "endurecer" la garantía constitucional del derecho, pero por perseguir este fin paga un precio no indiferente: debe proceder a realizar distinciones arduas y dolorosas entre aquello que en abstracto entra y aquello que está fuera de lo garantizado constitucionalmente [...], lo que implica la búsqueda del fin de la garantía constitucional, esto es, la individualización de un "valor" (la democracia, por ejemplo, en relación a la libertad de expresión) respecto al cual la garantía es servil.» ${ }^{142}$

Desde esta perspectiva, como nuevamente anota Scaccia, cabe observar que la definición en abstracto de los límites a los que está sujeto un derecho - en el cual, al final, se resuelve la categorical balancing-, no es una actividad de ponderación en sentido propio, sino de interpretación. "Una vez definido en abstracto el confín que separa las actividades protegidas de aquellas no protegidas, se introduce en la argumentación, en efecto, un elemento de rigidez que no solo impide tener en cuenta las circunstancias de hecho que puedan sugerir una solución diversa como la que expresa la aplicación de la regla "definitoria» del balancing, sino también hace problemática la expansión del área de tutela del derecho a otros intereses homogéneos». ${ }^{143}$

Por lo general, la ponderación definitoria es una técnica gravitante en el control abstracto de constitucionalidad de las leyes. En tales procesos, ausente la defensa de un derecho subjetivo de una de las partes, el conflicto se resuelve con prescindencia de las circunstancias concretas donde podría aplicarse la norma. Lo que no sucedería, desde luego, si se tratara de un supuesto de conflicto entre libertad de información y derecho al honor entre dos particulares, en el que la solución del conflicto entre derechos se obtendrá a partir de las circunstancias del caso.

\section{b) Ad hoc (o case by case) balancing}

En cambio, en el segundo (v. gr. en un amparo o habeas corpus), el conflicto se resuelve en función de cada caso, tomando en cuenta los intereses en conflicto y las circunstancias específicas que subyacen en él. Por su propia naturaleza, en este último se parte de la enunciación de una regla

141 Gino Scaccia, "Il bilanciamento degli interessi come tecnica di controllo costituzionale», en: Giurisprudenza Costituzionale, op. cit., pp. 3966-3967.

142 Roberto Bin, Diritti e argomenti. Il bilanciamento degli interessi nella giurisprudenza costituzionale, op. cit., p. 65, nota $\mathrm{N}^{\circ} 160$.

143 Gino Scaccia, "Il bilanciamento degli interessi come tecnica di controllo costituzionale», en: Giurisprudenza Costituzionale, op. cit., p. 3967. 
estable de solución del conflicto, pero la solución del problema se determina en función de las circunstancias del caso. A juicio de Riccardo Guastini, en tales supuestos el operador judicial establece una «jerarquía axiológica móvilı, pues soluciona el caso estableciendo una relación jerárquica entre dos principios, en razón de las particularidades del caso, en la que en la solución del problema se toma en consideración el posible impacto de su aplicación. "Se trata de una relación de valor inestable, mudable, que vale para el caso concreto, pero que podría invertirse en relación con un caso concreto diversom. ${ }^{144}$

«Dicho más claramente, también una decisión ad hoc es formalizable en términos de (aplicación de una) regla general, pero la diferencia respecto a la decisión definitional es que en el primer caso el juez no enuncia la regla, o sea, no declara seguir una regla (también jurisprudencial) preconstituida, y tampoco dice que el criterio para la solución de aquel específico caso (aquella regla) será aplicable a todos los casos futuros con elementos similaresm. ${ }^{145}$

La expresión "ponderación» o «balancing», en este último supuesto, sugiere una actividad decisoria no guiada por reglas generales y determinadas, sino en virtud de demandas del caso concreto; más que una solución a través de la scientia juris, ésta se obtiene mediante la prudentia juris, al menos por las siguientes razones: en primer lugar, porque se atribuye a un derecho o a un principio, en el caso concreto, una preferencia, al amparo de un juicio de valor que no se deriva según algunos del documento normativo (que les asigna el mismo rango), sino del intérprete, que «instituye un orden de preferencia». En segundo lugar, como se ha expuesto, nada garantiza que en un caso futuro se arribe a las mismas conclusiones, al mismo orden de preferencia, en la medida que, en abstracto, los dos derechos tienen el mismo rango. Desde esta perspectiva, como anota Guastini, ponderar no quería decir tanto balancear o encontrar un punto de equilibrio, sino, sobre todo, sacrificar un principio a favor del otro. ${ }^{146}$

144 Riccardo Guastini, «Principios de derecho y discrecionalidad judicial», en: Estudios de Teoría Constitucional, UNAM-Fontamara, México, 2001, p. 146.

145 Giorgio Pino, "Teoria e pratica del bilanciamento: tra libertá di manifestazione del pensiero e tutela dell'identitá personales", en: Danno e Responsabilitá, op. cit., p. 581.

146 De ahí que, a juicio de Guastini, la ponderación consista en establecer entre los principios o derechos que se encuentran en conflicto, una «jerarquía axiológica móvil» Cfr. 
El caso más notorio de aplicación de esta técnica — no tanto porque el problema pasaba por realizar un balancing ad hoc, sino por lo que allí se expresaría - pudo constatarse en un problema donde el definitional balancing que el Tribunal Constitucional había efectuado en torno a los alcances del derecho al procedimiento pre-establecido por la ley le impedían resolver un problema de un modo satisfactorio. Los antecedentes de ese caso son los siguientes. Hasta antes de la STC recaída en el Exp. $\mathrm{N}^{\circ}$ 577-2000-AA/TC, el Tribunal Constitucional había considerado que mediante el derecho al procedimiento pre-establecido por la ley se había protegido constitucionalmente la observancia de todas las reglas procedimentales que en dicha fuente se hubiera previsto $y$, en forma particular, con las que regulaban el procedimiento administrativo. Ello lo había llevado a declarar inválidos, por ejemplo, procedimientos administrativos disciplinarios cuya sanción se hacía pública fuera del plazo legalmente establecido. Sin embargo, en un caso similar, donde al parecer las faltas cometidas habían sido tan graves que colindaban con la comisión de un ilícito penal, pero donde a su vez la sanción impuesta al servidor fue expedida fuera del plazo legalmente establecido, el Tribunal tuvo que reconsiderar sus alcances en torno a este derecho, pues la construcción pasada se presentaba como "excesivamente formalista" $y$, en consecuencia, era preciso una "necesaria ponderación", pues, «de otro modo, cualquier formalidad podría convertirse en un reclamo constitucional, no precisamente legítimom. ${ }^{147}$

Riccardo Guastini, "Principios de derecho y discrecionalidad judicial», en: Estudios de Teoría Constitucional, op. cit., pp. 146-147.

147 STC $N^{\circ}$ 577-2000-AA/TC, Fund. Jur. $N^{\circ} 3^{\circ}$ y $4^{\circ}$. Problema distinto es la argumentación empleada por el Tribunal, pues, en realidad, el tema pudo haberse resuelto replanteando los alcances del derecho en referencia, como posteriormente se hizo. Se trata de un sentencia que marca el inicio del fin de tal concepción, pues en sentencias dictadas con la nueva composición del Tribunal, este ha sido enfático en señalar que el derecho al procedimiento pre-establecido por la ley solo garantiza que las modificaciones procesales que se pudieran realizar no pueden aplicarse, a no ser que sean más favorables, a los procesos o actos procesales iniciados durante la vigencia de la norma procesal modificada: Así, por ejemplo, en la STC recaída en el Exp. N²928-2002-HC/TC: «este Tribunal debe recordar que el derecho al procedimiento preestablecido por la ley no protege al sometido a un procedimiento por cualquier transgresión de ese procedimiento, sino solo vela porque las normas de procedimiento con las que se inició su investigación, no sean alteradas o modificadas con posterioridad" (Fund. Jur. $\mathrm{N}^{\circ} 3^{\circ}$ ). 
Por ese tipo de efectos, no es casual que sobre el test de la ponderación se hayan levantado serias críticas. ${ }^{148}$ Así, por ejemplo, en la doctrina italiana, Alessandro Pace ${ }^{149}$ ha sido muy crítico con aquellas corrientes que propugnan una teoría de los valores en la constitución (v. gr. Baldessare ${ }^{150}$ - Zagrebelsky) ${ }^{151}$ y la afirmación de que es "el caso" a determinar lo que condiciona la elección del método interpretativo aplicable. A su juicio, la tesis casuística no solo conduce a la sustitución del «Estado de derecho» por el "Estado de justicia», ${ }^{152}$ sino que, simultáneamente, un tipo de interpretación semejante prescinde de las propias disposiciones constitucionales. ${ }^{153}$ Criticando a Baldessare, ha sostenido que la interpretación normativa-sustancial, que sustituye a lo normativo-formal, en la práctica, supone que el intérprete sobreponga su propia jerarquía cultural a aquella expresada en el texto constitucional.

Por su parte, Alesandro Mangia ha destacado que «el balancing de intereses es fruto de una idea de "constitución como instrumento de control social», omnicomprensivo, pero también privado de contenido normativo fijo y predefinido, que lleva a una «fragmentación y modulación de la eficacia normativa de la Constitución en relación al caso examinado». ${ }^{154}$

A fin de hacer frente a estas críticas, los propugnadores del balancing han reparado sobre la necesidad de articular un determinado procedimiento para hacerlo más racional y previsible. Como dice Alexy, tales exigencias demandan la no contradicción, universalidad, claridad lingüística, clari-

148 Sobre la necesidad de establecer reglas al balancing que lo constriñan y hagan previsible los resultados de su implementación, Omar Chessa, "Bilanciamento ben temperato o sindacato esterno di ragionevolezza:n, en: Giurisprudenza Costituzionale, No 6, 1998, p. 3925 y ss. Cfr. también Giancarlo Rolla, "El valor normativo del principio de la dignidad humana" en: Anuario Iberoamericano de Justicia Constitucional, $\mathrm{N}^{\circ} 6,2002$, p. 482 y ss, donde se alude a la necesidad de establecer vínculos materiales y procedimentales al ad hoc balancing.

149 Alessandro Pace, "Metodi interpretativi e costituzionalismo", op. cit., p. 52.

150 Antonio Baldassare, "Costituzione e teoria dei valori» en: Politica del Diritto, $\mathrm{N}^{\circ}$ 4,1991, p. 639 y ss.

151 Cfr. Gustavo Zagrebelsky, El Derecho Dúctil. Ley, derechos, justicia, Editorial Trotta, Madrid, 1999, passim.

152 Alessandro Pace, "Metodi interpretativi e costituzionalismo", op. cit., p. 53.

153 Alessandro Pace, op. cit., p. 55.

154 Alessandro Mangia, "Valori e interpretazioni in Ernest Forsthoff», en: Jus, Rivista di scienze giuridiche, No 1, 1994, p. 6 y ss. La cita es de la p. 7 de su trabajo. 
dad conceptual, verdad empírica, consideración de los efectos y la ponderación. ${ }^{155}$

Cabe reparar, por otro lado, que aunque es frecuente considerar que el categorial balancing y el ad hoc balancing son modelos de ponderación entre principios constitucionales cuya aplicación depende del modelo de justicia constitucional de los derechos fundamentales [el primero, para los de raíz kelseniana; en tanto que el segundo, para los de la tradición de la judicial review], lo cierto del caso es que se tratan de técnicas que no se excluyen, y son utilizadas simultáneamente por los tribunales constitucionales.

En particular, la aplicación simultánea de ambos balancing ocurren en los modelos que tendencialmente admiten, en alguna forma, un control al modo de la judicial review, como sucede en el Perú; en el que el Tribunal Constitucional, como se ha recordado antes, no solo juzga en abstracto la validez de las leyes, sino también es un juez de casos (por ejemplo, cuando conoce del amparo, habeas corpus o el habeas data). En tales ocasiones, los resultados obtenidos a través de una regla definitoria no excluye que, en presencia de otros intereses, resultados irrazonables o injustos, puedan ser evitados mediante una ponderación ad hoc.

\section{c) La delegación del balancing}

Cabe observar, finalmente, que en ocasiones los tribunales constitucionales no realizan el balance o ponderación por sí mismos, sino que encargan que este se efectúe al momento de aplicarse la norma por el juez o por un órgano de la administración pública. Se tratan de supuestos en los que el Tribunal «no está en condición de dictar un nuevo y diverso orden de graduación de los intereses presentes, por ejemplo, por la complejidad de los hechos en los que habrá que aplicarse para dar contenido concreto a los principios que inciden sobre la materia, o a la imposibilidad de extraer de modo unívoco del sistema la "regla de prevalencia» válida para el caso en examen". Ello sucede con frecuencia en los procesos abstractos de inconstitucionalidad de leyes, donde por la naturaleza misma del control, no es posible observarse si pese a tratarse de una ley abstractamente válida, sin embargo, ha tenido o puede tener una aplicación inválida. En tales casos, el Tribunal Constitucional suele «delegar»

155 Robert Alexy, Teoría del discurso y derechos humanos, Universidad Externado de Colombia, Bogotá, 2001, p. 67. 
en los órganos que irán de aplicar la ley la realización del balancing de los bienes que se encontrarán en un eventual conflicto.

Así sucedió, por ejemplo, en la sentencia recaída en el Caso de la Legislación Antiterrorista (Exp. No 010-2002-AI/TC) en el tema de la limitación del derecho de defender de los letrados en materia de terrorismo. El inciso c) del artículo $2^{\circ}$ del Decreto Ley $N^{\circ} 25744$, en efecto, limitaba al abogado el derecho de patrocinar causas en materia de terrorismo, a no más de uno. Al desestimar la inconstitucionalidad, en términos generales, de dicho precepto, el Tribunal Constitucional, sin embargo, advirtió que

«esa negación de la incompatibilidad, per se, del inciso c) del artículo $2^{\circ}$ del Decreto Ley $\mathrm{N}^{\circ} 25744$ con la Convención Americana sobre Derechos Humanos, no puede sino entenderse en los alcances generales con los cuales está formulado dicho precepto legal, pero que, en su aplicación concreta, especialmente en un ámbito territorial donde no haya la posibilidad de elección entre diversos profesionales del derecho, por su ausencia, tal aplicación - ya que no la disposiciónsí pueda lesionar el derecho en cuestión" (fund. Jur. $\mathrm{N}^{\circ} 115$ ).

No debe pensarse, sin embargo, que esa delegación del balancing solo sea posible de efectuarse en un proceso abstracto de inconstitucionalidad de las leyes. En los procesos donde el Tribunal juzga sobre «casos» (amparo, habeas corpus, habeas data, etc.), este controla que los órganos judiciales o administrativas, al aplicar la ley, hayan efectuado la ponderación, por lo que la labor del Tribunal Constitucional (o la del Juez Constitucional) se reduce a verificar que este se haya practicado idóneamente. Ello es consecuencia del carácter vinculante de los derechos fundamentales $y$, por tanto, de su «efecto de irradiación» por todo el ordenamiento jurídico. $Y$ si bien es verdad que aquí, por lo general, no hay propiamente una delegación que el Tribunal confía en el órgano que aplica la ley, sí hay un control sobre si esas exigencias de ponderación se produjeron.

En ese último sentido, es paradigmática la sentencia recaída en el Exp. $\mathrm{N}^{\circ}$ 0499-2002-AA/TC. En dicho caso, las instancias judiciales ordinarias desestimaron, por la forma, un amparo, alegando que no se había agotado la vía administrativa-tributaria. Se impugnaba la inconstitucionalidad de la aplicación de un impuesto creado por ley y se alegaba que no se había transitado la vía administrativa, pues el Tribunal Fiscal se había declarado incompetente para inaplicar por inconstitucional 
una ley. El Tribunal Constitucional sostuvo que la exigencia de agotarse la vía administrativa constituía una «limitación del derecho de acceso a la justicia", por lo que debía "entenderse a la luz del principio pro actione» $y$, en ese sentido, -consideró- que el «agotamiento de la vía administrativa solo será exigible si su tránsito se configura como una vía idónea y eficaz para los fines que se persiguen con su instalación". Al señalar que era competente para conocer sobre el fondo del asunto, sostuvo que la exigencia de "agotarse nominalmente la vía administrativa-tributaria", como lo sostuviera la resolución recurrida, constituía «un exceso de ritualismo procedimental manifiesto [...] que, por ser ineficaz, dificulta irrazonablemente (el) derecho de acceso a la justicia». ${ }^{156}$

En definitiva, y volviendo al problema de la delegación de la ponderación, puede indicarse que este se presenta en todos aquellos casos en los que la incidencia sobre un derecho a través de la ley, en abstracto, no genera un problema de invalidez, sino que este puede presentarse en su aplicación. ${ }^{157}$ En el caso antes planteado, el problema no es tanto la legitimidad en abstracto de la ley, esto es, que sea inconstitucional que el legislador establezca, como condición de la acción, que antes de promover una acción judicial, se tenga que agotar la vía administrativa; sino que su exigencia, en un caso donde ésta no sea razonablemente exigible, afecte un derecho constitucional, como el acceso a un tribunal de justicia.

\subsubsection{Balancing, principio de proporcionalidad y principio de congruencia práctica}

Suele no distinguirse entre balancing, principio de proporcionalidad y el de concordancia práctica. Entre ellos, tal y como están formulados, existe una relación. El balancing es un elemento del principio de proporcionalidad. Entre tanto el principio de concordancia práctica comprende al principio de proporcionalidad.

\section{a) El principio de proporcionalidad}

El principio de proporcionalidad es una técnica cuyo ámbito de actuación está esencialmente delimitado a la intervención estatal en los dere-

156 Cfr. también las STC recaídas en los Exp. No 1260-2002-HC/TC, en materia de detención judicial preventiva; en materia de procedimientos administrativos sancionadores, la recaída en el Exp. N 1120-1999-AA/TC, especialmente, Fund. Jur. N³. 
chos fundamentales. ${ }^{158}$ Es decir, sirve como criterio de evaluación cada vez que so pretexto de optimizar un bien colectivo, el legislador introduce una disminución sobre lo protegido por un derecho fundamental. No rige, como se verá, en un conflicto entre derechos fundamentales, en cuyo caso la técnica de solución es la ponderación o balancing.

Descontado que está su reconocimiento como principio constitucional expreso, ex último párrafo del artículo $200^{\circ}$ de la Constitución, este principio se descompone en tres sub-principios o "mandatos parciales»: ${ }^{159}$ que la medida limitadora obedezca a un fin estrictamente basado en la Constitución, esto es, ha de observarse si el régimen limitativo del ejercicio del derecho tiene relación con aquellos derechos o bienes constitucionales que se buscan optimizar (examen de adecuación); que se trate de una medida necesaria o indispensable, es decir, que no exista una alternativa menos gravosa sobre el derecho afectado, que pueda servir también para alcanzar la finalidad pretendida (examen de necesidad); y, finalmente, el mandato de proporcionalidad en sentido estricto, que exige evaluar si la limitación introducida al derecho "constituye una medida equilibrada entre el perjuicio que sufre el derecho limitado y el beneficio que de ello se deriva en favor del bien público» (examen de proporcionalidad). ${ }^{160}$

Como afirma José María Rodríguez, además de requerirse una intervención estatal en la esfera de libertad personal para su aplicación, las exigencias de la proporcionalidad están presididas por la lógica de la relación de medio a fin. Es decir, se trata de analizar si la utilización de un determinado medio (la limitación del derecho) es proporcional para la consecución de cierto fin (bien colectivo). ${ }^{161}$

157 Roberto Bin, Diritti e argomenti. Il bilanciamento degli interessi nella giurisprudenza costituzionale, op. cit., pp. 122-123.

158 Sobre el tema, el monumental trabajo de Carlos Bernal Pulido, El principio de proporcionalidad y los derechos fundamentales, CEPC, Madrid, passim.

159 José María Rodríguez de Santiago, La ponderación de bienes e intereses en el derecho administrativo, Marcial Pons, Madrid, 2000, p. 25.

160 José María Rodríguez de Santiago, La ponderación de bienes e intereses en el derecho administrativo, op. cit., p. 25. Sobre la aplicación de tal principio en la jurisprudencia del Tribunal Constitucional Alemán, puede verse: Christian Starck, "I diritti fondamentali nel Grundgesetz della Repubblica Federale di Germania", en: Giurisprudenza Costituzionale, $\mathrm{N}^{\circ} 3,1992$, p. 2529 y ss. Jorg Luther, "Ragionevolezza e Verhaltnismabigkeit nella giurisprudenza costituzionale tedesca», en: Diritto e Societá, $N^{\circ} 1-2,1993$, p. 307 y ss.

161 Cfr. STC recaída en el Exp. N542-1997-AA/TC, sobre limitación del derecho de igualdad y las exigencias de una eficiente administración pública. 
b) El principio de concordancia práctica

El principio de concordancia práctica o, llamado también, de «armonización", es un criterio específico de interpretación de las normas constitucionales. Según ha expuesto Hesse, este exige del intérprete que «los bienes jurídicos constitucionalmente protegidos deben ser coordinados de tal modo en la solución del problema que todos ellos conserven su entidad. Allí donde se produzca colisiones no se debe [...] realizar el uno a costa del otro" En esos casos, «se hace preciso establecer los límites de ambos bienes a fin de que ambos alcancen una efectividad óptima». ${ }^{162}$

Este principio presupone que en caso de colisión de bienes constitucionales, esos "conflictos [...] no se resolverán de ordinario con la afirmación de la prevalencia incondicionada o absoluta de alguno sobre los demás", ${ }^{163}$ sino del modo que de mejor forma resulten ambos optimizados. «El juicio de concordancia práctica exige (imposición positiva) que el punto de equilibrio sea aquel en que los dos principios alcanzan su máximo grado de realización".. ${ }^{164}$

\section{c) La ponderación o balancing}

La ponderación es una técnica que puede distinguirse en "ponderación-actividad» ${ }^{165} \mathrm{o}$ "ponderación-procedimiento», ${ }^{166}$ es decir, como una actividad (intelectual o psicológica) de decisión de un conflicto entre derechos o entre éstos y principios.

Desde este punto de vista, la ponderación se traduciría en un modo de argumentar o fundamentar decisiones en derecho, caracterizada por seguir un esquema que se estructura en tres fases: en primer lugar, investigar

162 Konrad Hesse, Escritos de Derecho Constitucional, CEC, Madrid, 1992, pp. 46-47.

163 Juan José Solazábal, «Algunas cuestiones básicas de la Teoría de los Derechos Fundamentales", en: Revista de Estudios Políticos, op. cit., pp. 98-99. Cfr. en sentido inverso, entre nosotros, Francisco Eguiguren Praeli, « $\varsigma$ Tienen todos los derechos humanos igual jerarquía?», en: Ius et Praxis, N4, Lima, 1992, pp. 3-6.

164 José María Rodríguez de Santiago, La ponderación de bienes e intereses en el derecho administrativo, op. cit., p. 29

165 Así, Giorgio Pino, "Teoria e pratica del bilanciamento: tra libertá di manifestazione del pensiero e tutela dell'identitá personales", en: Danno e Responsabilitá, N 6, 2003, p. 577.

166 Es la expresión de José María Rodríguez de Santiago, La ponderación de bienes e intereses en el derecho administrativo, op. cit., p. 48 y ss. 
e identificar los principios en conflicto. Esta fase se identifica con lo que Roberto Bin denomina señalar la "topografía del conflicto». Es decir, describir, en el caso específico de que se trate, la forma cómo «la norma que tutela un determinado interés incide en el ámbito de tutela de un interés concurrente [...]. Trazar la topografia del conflicto significa, pues, responder a dos preguntas: a) si, y por qué extensión, el área de tutela del interés perseguido por la norma impugnada se sobrepone al área que debe ser garantizada por el interés con el cual se lamenta la compresión; b) qué espacio (identificada la zona de sobreposición) queda al ejercicio de alguno de los dos derechos en conflictosn. ${ }^{167}$

Una vez culminada esta primera fase, el Tribunal Constitucional debe atribuirles el peso o la importancia que corresponda a ambos bienes, conforme a las circunstancias del caso; $y$, en tercer lugar, decidir sobre la prevalencia de uno de ellos sobre el otro.

Pero también el balancing puede entenderse como "ponderación-producto", es decir, como una técnica de argumentación explicitada en una sentencia; a la decisión en sí o, lo que es lo mismo, a la solución correctamente argumentada, conforme al criterio de que cuanto mayor sea el grado de perjuicio del principio que ha de retroceder, mayor ha de ser la importancia del cumplimiento del principio que prevalece». ${ }^{168}$

En ese sentido, no debe confundirse a la ponderación con el principio de proporcionalidad. Cuando se trata de una intervención estatal en la esfera de un derecho constitucional, dado que el principio de proporcionalidad no se aplica en los conflictos entre derechos fundamentales de dos individuos, la ponderación se presenta como uno de los sub-criterios que forman parte del principio de proporcionalidad. ${ }^{169}$ Este constituye, en efecto, su «tercer escalón de un examen de cualquier medida limitativa de los derechos fundamentales desde el punto de vista de las exigencias del principio de proporcionalidad,. ${ }^{170}$

167 Rober Bin, Diritti e argomenti. Il bilanciamento degli interessi nella giurisprudenza costituzionale, op. cit., pp. 62-63.

168 José María Rodríguez de Santiago, La ponderación de bienes e intereses en el derecho administrativo, op. cit., pp. 48-49.

169 Pedro Serna, La interpretación constitucional de los derechos fundamentales, Editorial La Ley, Buenos Aires, 2001, passim.

170 José María Rodríguez de Santiago, La ponderación de bienes e intereses en el derecho administrativo, op. cit., p. 26. 
Sin embargo, lo anterior no debe llevar a considerar que no hay balancing o ponderación por fuera del principio de proporcionalidad o viceversa, que el balancing se confunda con el principio de proporcionalidad. La última afirmación es sencilla de explicar. El balancing es uno de los sub-criterios del principio de proporcionalidad para medir las intervenciones estatales en la esfera de los derechos fundamentales. Pero hay esferas o ámbitos en los que el conflicto debe solucionarse a través de la ponderación, sin que en dicho ámbito sea aplicable el principio de proporcionalidad. Ello sucede especialmente en los casos en los que el conflicto se produce entre dos derechos fundamentales, en los que la evaluación de los criterios de "utilidad», «necesidad" y "proporcionalidad en sentido estricto" no ingresan. "Aquí hay solo ponderación, que puede llevar a argumentaciones y a resultados, a veces, semejantes a los de la doctrina relativa al principio de proporcionalidad, pero que no se rige por ésta".

Finalmente, también cabe diferenciar a la ponderación del criterio de concordancia práctica. Como expresa José María Rodríguez, «la concordancia práctica postula la óptima efectividad posible de los principios o bienes en conflicto. Mientras que el juicio de simple ponderación impide (límite negativo) que un principio, valor o bien sea perjudicado en una medida que no esté justificada por la importancia del cumplimiento del principio contrario». De manera que «un determinado punto de equilibrio puede ser ponderado, pero no el óptimo (como exigiría el principio de concordancia práctica)». ${ }^{171}$

\subsection{La interpretación conforme con los tratados sobre derechos humanos}

Cuando el Estado incorpora a su derecho interno el Derecho Internacional de los Derechos Humanos, ese derecho interno ya no queda cerrado en la Constitución, sino coordinado y compatibilizado con el Derecho Internacional. El sistema de derechos, así, se fortalece cuando se enuncia, como en el caso de la Cuarta Disposición Final y Transitoria de la Cons-

171 José María Rodríguez de Santiago, La ponderación de bienes e intereses en el derecho administrativo, op. cit., p. 29.

172 Cfr. Edgar Carpio y Carlos Mesía, Amparo y derechos fundamentales, op. cit., p. 40 y ss. 
titución de 1993, que los derechos contenidos en la Constitución se deben interpretar de conformidad con los tratados internacionales de derechos bumanos. ${ }^{172}$

Disposiciones de esta naturaleza, como expresa Antonio Cançado, ya no justifican "que el derecho internacional y el derecho constitucional sigan siendo abordados de forma estática o compartimentalizada». ${ }^{173}$ Exige, por el contrario, que se las aborde en forma dinámica e integral y, por tanto, que el intérprete concilie ambas fuentes que forman parte de un único sistema de derechos. Lo que significa que antes de presumir incompatibilidades o efectuar confrontaciones entre ambas, existe un deber de integrarlas y descifrar en ellas un contenido armonizante y congruente de los derechos fundamentales. ${ }^{174}$

Aquí adquiere su mayor vigor el principio de optimización de los derechos fundamentales así como el de la fuerza expansiva de los derechos humanos. Como afirma Bidart: ${ }^{175}$ «la fuente interna y la internacional se retroalimentan. Los egoísmos interpretativos, cualquiera sea su origen y cualquiera el método que empleen para reducir el sistema en vez de procurar su ampliación y plenitud, no obedecen ni responden condignamente a la génesis y a la razón histórica del sistema de derechos, que nunca fue ni pudo ser - ni debe ser- de estrechez o angostamiento, sino de optimización, en un marco histórico y situacional [...]».

Definitivamente, esa era la impronta que cumplía el artículo $105^{\circ} \mathrm{de}$ la Constitución peruana de 1979 , que por primera vez en el constitucionalismo latinoamericano otorgó rango constitucional a los tratados sobre derechos humanos. Y es que si en el plano jurídico formal, ello implicaba admitir que la Constitución de 1979 no se reducía a los trescientos siete (307) artículos que tenía, pues también comprendía a todas las disposiciones de los tratados sobre derechos humanos; desde una perspectiva jurídica sustantiva, la concesión de tal rango a los derechos

173 Antonio Cançado Trindade, «Reflexiones sobre la interacción entre el Derecho Internacional y Derecho Interno en la protección de los Derechos Humanos», en: AA.VV., VCongreso Iberoamericano de Derecho Constitucional, UNAM, México, 1998, p. 109. Cfr. asimismo, Héctor Fix-Zamudio, "Los tratados internacionales de derechos humanosy las constituciones latinoamericanas", en: AA.VV., V Congreso Iberoamericano de Derecho Constitucional, op. cit., p. 317 y ss.

174 Germán Bidart Campos, "La interpretación de los derechos humanos", op. cit., p. 30.

175 Germán Bidart Campos, op. cit., pp. 30-31. 
reconocidos en los instrumentos internacionales se traducía en un tratamiento unitario y dinámico de los derechos esenciales del ser humano.

Aunque la Constitución de 1993 no reprodujo similar tratamiento, bajo la inspiración del artículo 10.2 de la Constitución española de 1978, estableció en la IV Disposición Final y Transitoria que «las normas relativas a los derechos y a las libertades que la Constitución reconoce se interpretan y aplican de conformidad con la Declaración Universal de Derechos Humanos y con los tratados y acuerdos internacionales sobre las mismas materias ratificados por el Perú».

Diversas son, desde luego, las funciones que una cláusula constitucional de esa naturaleza está llamada a desempeñar. En primer lugar, puede afirmarse que con su inserción, la Ley Fundamental ha querido poner en evidencia que, por genéricas, abiertas y valorativas que puedan ser las disposiciones que reconocen derechos fundamentales, la cuestión del desciframiento o asignación de sus alcances, límites o restricciones, no es un tema que el intérprete jurisdiccional pueda libre y discrecionalmente disponer, sino que se trata de una actividad reglada. Ha de buscarla o hallarla, primeramente, en la Declaración Universal de Derechos Humanos y en los tratados sobre la materia en los que el Estado peruano sea parte. Con ello la Constitución disciplina jurídicamente la actividad interpretativa de sus operadores jurídicos (y, en particular, de los órganos jurisdiccionales) en torno a los derechos y libertades que ella pueda haber reconocido. Y es que si las cláusulas que reconocen derechos fundamentales son previsiones dotadas de un alto grado de abstracción, y por ello suele reconocérsele al intérprete de un amplio margen para efectuar su interpretación, ello no quiere decir que tal actividad se encuentre exenta de límites, ${ }^{176}$ límites que no solo deben reconducirse a lo formulado en las propias disposiciones constitucionales, sino que, en materia de derechos fundamentales, también cabe extender al sentido, función y significado de los tratados sobre derechos humanos.

En segundo lugar, la IV Disposición Final y Transitoria de la Constitución atribuye a la Declaración Universal de los Derechos Humanos y a los tratados sobre la misma materia una "función hermenéutica», ${ }^{177}$ que se

176 Cfr. Pablo Pérez Tremps, «La interpretación de los derechos fundamentales», en: Luis López Guerra (Coordinador), Estudios de Derecho Constitucional. Homenaje al Profesor doctor don Joaquín García Morillo, op. cit., pp. 120-121.

177 Cfr. Susana Castañeda Otsu, «La interpretación conforme a los tratados sobre 
despliega precisamente sobre las disposiciones constitucionales que reconocen derechos fundamentales. De esta forma, independientemente del rango que puedan tener los tratados en el derecho nacional, la Constitución ha impuesto a los operadores jurisdiccionales que sus disposiciones en materia de derechos fundamentales deban ser interpretadas de conformidad con los tratados sobre derechos humanos.

Con ello se ha constitucionalizado un auténtico criterio de interpretación de los derechos fundamentales, a diferencia de lo que sucede con otros criterios que, como se ha visto, son básicamente de origen pretoriano. ${ }^{178}$ Pero la introducción de un canon hermenéutico de interpretación de los derechos fundamentales, como el que contiene la IV Disposición Final y Transitoria de la Constitución, no solo debe entenderse como referido a las cláusulas constitucionales que contienen derechos, sino, en general, a todas aquellas leyes relativas a derechos y libertades fundamentales (v. gr. las que precisan sus alcances o establecen restricciones). ${ }^{179}$

De esta forma, se complementa el principio de interpretación de la ley conforme a la Constitución. Y es que si ésta exige que todas las leyes y normas de igual o inferior jerarquía deban ser interpretadas y aplicadas conforme a la Constitución; el principio de interpretación conforme con los tratados sobre derechos humanos exige que todas normas del ordenamiento, relativas a derechos fundamentales, con independencia del rango

derechos humanos en la Constitución peruana de 1993", en: Revista Peruana de Derecho Público, $\mathrm{N}^{\circ}$ 2, 2001, pp. 58-59. Marco Ruotolo, "La funzione ermeneutica delle convenzioni internazionali sui diritti umani nei confronti delle disposizioni costituzionali", en: Diritto e Societá, $N^{\circ} 2,2000$, p. 291 y ss.

178 No obstante lo que se afirma en el texto, y la importancia de este precepto, no puede dejarse de compartir la opinión de Gregorio Peces Barba, para quien, en efecto, «su incidencia en la interpretación de los operadores jurídicos, viene ya exigida por el mismo sentido del criterio sistemático (de interpretación de las normas). Es decir, si nos fijamos en este criterio y además, somos conscientes de que las normas internacionales ratificadas [...] son normas jurídicas de nuestro sistema, tendremos que concluir que su incidencia en la interpretación de los derechos es clara, aún sin el artículo 10.2", que es la disposición de la Constitución española de donde se ha embebido la IV Disposición Final y Transitoria de la Constitución peruana de 1993. Gregorio Peces Barba, Curso de Derechos Fundamentales. Teoría general, Universidad Carlos III de Madrid-BOE, Madrid, 1995, p. 585.

179 Cfr. Giampaolo Gerbasi e Donatella Loprieno, «L'apertura del diritto costituzionale al diritto internazionale dei diritti umani negli ordinamenti dell'Europa continentalen, en: Diritto Pubblico ed Comparato, 2002-II, p. 1115 y s. 
que puedan tener, deban también ser interpretadas de conformidad con ellos. Como lo ha dicho el Tribunal Constitucional español, «tanto las normas constitucionales como las internacionales [...] deben servir de base para la interpretación de las normas legislativas" (STC 40/1987; F. Jur. $N^{\circ}$. 2). ${ }^{180}$

Finalmente, una de las consecuencias más relevantes de este criterio interpretativo de los derechos fundamentales tiene que ver con las propias cláusulas de interpretación de los derechos que se hallan en los tratados sobre derechos humanos. En efecto, si, como declara el artículo $55^{\circ}$ de la Constitución, los tratados ratificados por el Estado peruano forman parte del derecho nacional, entonces ello quiere decir que las disposiciones interpretativas previstas en los tratados tienen que ser necesariamente instrumentalizados por los órganos de la jurisdicción interna.

Es el caso, entre otras, de las disposiciones interpretativas previstas en la Convención Americana de Derechos Humanos, que complementan a los criterios antes señalados $y$, particularmente, los siguientes:

a) Ninguna disposición de la Convención (pero también de la Constitución o las leyes), debe ser interpretada en el sentido que permita al Estado, grupo o persona de suprimir el goce y ejercicio de los derechos y libertades reconocidos en la Convención o limitarlos en mayor medida que la prevista en ella.

Desde este punto de vista, el operador no debe perder de vista que en la interpretación de los límites de los derechos reconocidos en la Convención ha de observarse el principio pro homine. Aún así, el artículo $30^{\circ}$ de la misma Convención establece que, en materia de limitaciones a los derechos, la sola vigencia del Pacto de San José o su condición de parte del derecho nacional (ex artículo $55^{\circ}$ de la Constitución) no autoriza a entender que las limitaciones por él contemplados inmediatamente surtan sus efectos, pues «Las restricciones permitidas, de acuerdo con esta Convención, al goce y ejercicio de los derechos y libertades reconocidas en la misma, no pueden ser aplicadas sino conforme a leyes que se dictaren por razones de interés general y con el propósito para el cual han sido establecidas".

$180 \mathrm{Cfr}$. Ernesto Vidal Gil, «La interpretación de los derechos fundamentales por el Tribunal Constitucional», en: Corts. Anuario de Derecho Parlamentario, $N^{\circ} 11,2001$, p. 85 y ss. 
b) La Convención expresa el «standard mínimo» del contenido protegido por cada uno de los derechos fundamentales, de manera que las disposiciones de la Convención, no podrán ser interpretadas en el sentido de «Limitar el goce y ejercicio de cualquier derecho o libertad que pueda estar reconocido de acuerdo con las leyes de cualquiera de los Estados partes o de acuerdo con otra Convención en que sea parte uno de dichos Estados».

En ese sentido, el principio recepcionado por el inciso b) del artículo $29^{\circ}$ de la Convención, exige del intérprete considerar que el principio de la mayor protección de los derechos fundamentales le impone aplicar el derecho interno, antes que el internacional, si el primero dispensa una mejor optimización del derecho fundamental.

c) Asimismo, la Convención Americana de Derechos Humanos constituye el «standard mínimo» en el reconocimiento de derechos y libertades fundamentales, es decir, el referente primario de aquello que debe considerarse como derecho fundamental en el Estado constitucional de derecho, de manera que sus disposiciones tampoco pueden interpretarse en el sentido de «Excluir otros derechos y garantías que son inherentes al ser humano o que se derivan de la forma democrática representativa de gobierno». De esta manera, se impone al intérprete de los derechos fundamentales no olvidar que la tabla de derechos - de la Constitución y de los tratados sobre derechos humanos- no puede considerarse cerrada. Se trata, por el contrario, de un "jardín de derechos", siempre abierto a las nuevas e indeterminadas demandas de protección de exigencias primarias y esenciales del ser humano, aunque éstas no se hallen positivizadas. ${ }^{181}$

d) Finalmente, el intérprete no debe descuidar que el principio pro homine es un principio en materia de interpretación de los derechos fundamentales, lo que exige, según se ha visto, la aplicación de una norma del modo más favorable posible, y la de su interpretación también. En ese sentido, tampoco las disposiciones de la Convención pueden ser interpretadas en el sentido de «excluir o limitar el efecto que puedan producir la

181 Cfr. Giusseppe Campanelli, "Le clausole d'apertura in materia di diritti fondamentali: un'ipotesi di comparaziones, en: Diritto Pubblico Comparato ed Europeo, 2002-I, p. 79 y ss. Antonio Ruggeri, "Nuovi" diritti fondamentali e tecniche di positivizzazione", en: Politica del Diritto, No 2, 1993, p. 183 y ss. Permítaseme la remisión a mi trabajo, Edgar Carpio Marcos, «El significado de la cláusula de los derechos no enumerados", en: Cuestiones Constitucionales, Revista mexicana de derecho constitucional, $N^{\circ} 3,2000$, p. 3 y ss. 
Declaración Americana de Derechos y Deberes del Hombre y otros actos internacionales de la misma naturaleza». ${ }^{182}$

Así, el principio de interpretación de conformidad con los tratados sobre derechos humanos, termina alcanzando su máxima virtualidad: la conformidad de las disposiciones constitucionales a los tratados no es a cualquier clase de tratado, sino al instrumento internacional que dispensa una mejor optimización del derecho. Desde luego, tal constitucionalización de esta técnica interpretativa de los derechos fundamentales no ha pasado desapercibida para nuestro Tribunal Constitucional. Por el contrario, a ella se ha referido constantemente. Así, por ejemplo, en el Caso Alfredo Crespo Bragayrac (Exp. Nº 0217-2002-HC/TC), el Tribunal afirmaría:

«De conformidad con la IV Disposición Final y Transitoria de la Constitución Política del Estado, los derechos y libertades reconocidos en la Constitución deben interpretarse de conformidad con los tratados internacionales en materia de derechos humanos suscritos por el Estado Peruano" (Fund. Jur. $\mathrm{N}^{\circ} 2$ ).

Pero los alcances que se han atribuido a dicha Disposición Final y Transitoria de la Constitución no solo han quedado en afirmar que allí se encuentra disciplinada la actividad interpretativa de los operadores jurídicos en materia de derechos o en la constitucionalización de una técnica de la interpretación de los derechos constitucionales. ${ }^{183}$ Apoyándose en esta última, el Tribunal Constitucional ha sostenido que de ella se infiere otra técnica de interpretación de los derechos, pues comprende o se extiende a la interpretación que de los tratados puedan haber realizado los órganos de protección de los derechos humanos y, en particular, la expresada por la Corte Interamericana de Derechos Humanos.

«Tal interpretación, conforme con los tratados sobre derechos humanos, contiene, implícitamente, una adhesión a la interpretación que, de

182 Cfr. Oscar Fappiano, El Derecho de los Derechos Humanos, Editorial Abaco, Buenos Aires, 1997, p. 60 .

183 Por cierto, el modelo de la IV Disposición Final y Transitoria de la Constitución no tiene su origen en la Constitución española de 1978, sino en la Constitución portuguesa de 1976. Sobre el particular, Jorge Miranda, "A recepcao da Declaracao Universal dos Direitos do Homem pela Constituicao Portuguesa. Um fenómeno de conjugacao de Direito Internacional e Direito Constitucionab, en: AA.VV., V Congreso Iberoamericano de Derecho Constitucional, UNAM, México, 1998, p. 499 y ss. 
los mismos, hayan realizado los órganos supranacionales de protección de los atributos inherentes al ser humano y, en particular, el realizado por la Corte Interamericana de Derechos Humanos, guardián último de los derechos en la Región" (Exp. Nº. 0218-2002-HC/TC, Fund. Jur. Nº 2).

Ciertamente, con la recepción de ambas técnicas de interpretación de los derechos fundamentales se ha dotado de una capacidad de "autointegración» a la Constitución, ${ }^{184}$ no tanto en el sentido de que el número de sus disposiciones se haya ampliado considerablemente (es decir, que a los doscientos seis (206) artículos y sus disposiciones finales y transitorias se hayan sumado un número indeterminado de disposiciones de los tratados sobre derechos humanos), sino en el sentido de que, un gran número de ellas y, en particular, las que reconocen derechos fundamentales tienen la capacidad de recibir de los tratados sobre derechos humanos una orientación en el proceso de comprensión al que están sujetos.

Por cierto, esta función de la jurisprudencia de los órganos de protección de los derechos humanos en la interpretación de los derechos fundamentales no se ha reducido solo a la de la Corte Interamericana de Derechos Humanos. También comprende a los pronunciamientos del Comité de Derechos Humanos de Naciones Unidas (STC en el Exp. Nº0181996-AI/TC) y a los informes de la Comisión Interamericana de Derechos Humanos (STC en los Exp. Nos. 0010-2002-AI/TC; 1091-2002HC/TC; 0791-2002-HC/TC o 1260-2002-HC/TC).

Por otro lado, tampoco han faltado remisiones a la jurisprudencia de otros tribunales, a las que, en principio, no existe una exigencia de seguimiento de sus doctrinas jurisprudenciales. En particular, cabe destacar la asunción de ciertos criterios expuestos por el Tribunal Europeo de Derechos Humanos (así, por ejemplo, las STC recaídas en los Exp. Nos. 0022001-AI/TC; 1429-2002-HC/TC y 2050-2002-AA/TC); que también se ha extendido a la de otros tribunales constitucionales análogos, como el alemán, español, italiano y, en menor medida, el colombiano. ${ }^{185}$

184 Cfr. sobre el tema las interesantes reflexiones de Marco Ruotolo, «La «funzione ermeneutica» delle convenzioni internazionali sui diritti umani nei confronti delle disposizioni costituzionalin, en: Diritto e Societá, N², 2000, p. 291 y ss.

185 Este recurso a la jurisprudencia constitucional comparada pone en evidencia que el modelo de Estado Constitucional es, en principio, un modelo homogéneo, que tiene por virtualidad relativizar las tradiciones constitucionales de cada país, al menos en torno a los derechos fundamentales. Así, Thomas Wurtenberger, «Interpretación del Derecho Cons- 
De esta manera, al interpretarse los derechos fundamentales, también se ha considerado como especialmente útil el recurso no solo a los textos legislativos del derecho interno, sino también al derecho internacional de los derechos humanos y al derecho constitucional comparado, ${ }^{186}$ que no solo comprende las disposiciones de cualquiera de los textos normativos, sino también a lo que de ellos hayan podido señalar sus intérpretes oficiales. $^{187}$

\section{8. Derechos sociales y principio de progresividad}

Un criterio de interpretación relacionado a una familia específica de derechos fundamentales - los denominados derechos sociales, económicos y culturales-, es el que se encuentra constitucionalizado, de modo general, en la Undécima Disposición Final y Transitoria de la Constitución, según el cual:

"Las disposiciones de la Constitución que exijan nuevos o mayores gastos públicos se aplican progresivamente».

Ciertamente, la Undécima Disposición Final de la Constitución es, en principio, una cláusula que tiene el propósito de recordar que aunque todas las disposiciones de la Constitución tienen fuerza normativa, no todas ellas tienen el mismo grado de eficacia. En particular, carecen de esa eficacia inmediata todas aquellas disposiciones constitucionales cuya efec-

titucional (desde una perspectiva realista)", en: Anuario Iberoamericano de Justicia Constitucional, $\mathrm{N}^{\circ}$ 6, Madrid, 2002.

186 Advirtiendo, no obstante, la necesidad de emplear este método de comparación con cierta precaución y ejerciendo, además, una función de control sobre textos normativos, Klaus Stern, Derecho del Estado de la República Federal Alemana, CEC, Madrid, 1987, p. 283.

187 Sobre la comparación jurídica como el "quinto método de interpretación», también aplicable a los derechos fundamentales, y el uso de la jurisprudencia como «método interpretativo universal», Cfr. Peter Häberle, "La jurisprudencia constitucional de los derechos fundamentales. Fuerza normativa e interpretación de los derechos fundamentales», en: Antonio López Pina (Director), La garantía constitucional de los derechos fundamentales. Alemania, España, Francia e Italia, Civitas, Madrid, 1991, pp. 271-273. Idem, "Linee di sviluppo della Giurisprudenza della Corte Costituzionale federale tedesca in materia di diritti fondamentalin, en: Giurisprudenza Costituzionale, N ${ }^{\circ} 4,1996$, pp. 28992900 . 
tividad demanda gastos estatales, entre los cuales se encuentran, desde luego, los derechos sociales. ${ }^{188}$

El principio de progresividad establecido en la Undécima Disposición Final y Transitoria de la Constitución exige del intérprete evaluar, en cada caso concreto, no solo que el legislador no establezca medidas regresivas, esto es, destinadas a reducir los ámbitos de eficacia ya alcanzados, sino también a evaluar que, en relación con los que no hayan sido objeto de ninguna prestación estatal, que tal situación no permanezca en el mismo status quo que lo dejó el constituyente.

Progresividad en su implementación supone la realización de medidas destinadas a hacerlas efectivas, paso a paso, y no que las pocas que se hayan efectuado se desarticulen. Pero, de otro lado, exigen del intérprete efectuar un control, cada intervalo razonable de tiempo, sobre si el letargo estatal (no solo del legislador), acaso no ha culminado en una afectación, por omisión, de la Constitución. Y es que el criterio de progresividad en su implementación no solo no se reduce a evaluar comportamientos regresivos, sino, también, a controlar que dichas cláusulas progresivamente sean implementadas para adquirir su plena eficacia.

No obstante, el Tribunal en su sentencia recaída en el Exp. $\mathrm{N}^{\circ} 083-$ 92-AA/TC, ha señalado que:

"Que como se puede observar, la naturaleza de la norma objeto de atención, si bien es de índole programática, y por tanto, generadora de una obligación por parte del Estado, no posee solamente los caracteres de aquellas que solo requieren para su vigencia, de una previa reglamentación legal, sino los de aquellas, que, además conllevan, la necesaria habilitación de condiciones económicas para que su ejercicio pueda tornarse efectivo. No en vano, forma parte de una norma de contenido eminentemente presupuestal. El problema en cuestión, no es entonces, un asunto baladí, sino que colinda directamente con la Teoría Constitucional y la explicación que aquella otorga a la operatividad inmediata o mediata de unas normas constitucionales por sobre otras. Que dentro de dicha lógica, si bien es cierto, que se puede tornar exigible una norma que solo requiera previa reglamentación y cuyo incumplimiento se ha venido prolongando duran-

188 Cfr. Christian Courtis, "Los derechos sociales como derechos", en: AA.VV., Los derechos fundamentales, op. cit., p. 197 y ss. 
te un periodo de tiempo notoriamente irrazonable, no se puede aplicar el mismo criterio, esto es, el de demandar la exigibilidad de una norma, cuando aquella además de la reglamentación demanda la creación de condiciones económicas, como ocurre en el presente caso, ya que ello, no es ni podría ser, materia de evaluación conforme a criterios jurisdiccionales, sino de exclusiva competencia política. Asumir una idea contraria, seria obligar a los jueces, ya sea ordinarios o especializados a emitir fallos no precisamente ajustados a Derecho sino a la discrecionalidad correspondiente solo a los órganos políticos. Que concordante con ello, la misma Constitución Política de 1979, bajo cuya vigencia se interpone la presente acción, estableció en su Disposición General y Transitoria que "Las disposiciones constitucionales, que irrogan nuevos gastos e inversiones, se aplican progresivamente [...]", motivo por el que la propia Ley $\mathrm{N}^{\circ} 23506$, haciendo eco de tal opción, señaló, en su artículo $25^{\circ}$, que «No dan lugar a la acción de amparo los derechos a que se refiere la Sexta de las Disposiciones Generales y Transitorias de la Constitución». Es en consecuencia, la idea de la "progresividad" y no, la de la inmediatez, la que explica el carácter de normas, como la que aquí se analiza. Que aunque las asociaciones demandantes, han pretendido objetar que la norma cuya reglamentación se exige, no es en todo caso constitucional, sino legal, los derechos sobre los cuales se apoyan si son de relevancia fundamental y de allí que se aplique en tal circunstancia la misma regla, independientemente, que, por otra parte, sería absurdo entender que las normas programáticas de tipo económico pueden variar su naturaleza conforme a su jerarquía legal o, en su caso, constitucional. Que por consiguiente, si bien este Colegiado asume, que no es imposible demandar la inconstitucionalidad por omisión legislativa proveniente de los Poderes Públicos, ya que a la Constitución no solo se le transgrede por lo que se hace, sino por lo que se deja de hacer, también entiende, que ello solo es viable o procedente, de acuerdo al tipo de norma programática cuya exigibilidad se invoque, descartándose dentro de tal contexto las de tipo económico, como se dijo, por no ser materia de análisis en sede jurisdiccional». ${ }^{189}$

189 Un comentario a dicha sentencia en Juan Carlos Morón Urbina, «La omisión legislativa inconstitucional y su tratamiento jurídico", en: Revista Peruana de Derecho Constitucional, $\mathrm{N}^{\circ} 1$, Lima, 1999, p. 447 y ss. 